\title{
Recent Developments on 1,3-Dipolar Cycloaddition Reactions by Catalysis in Green Solvents
}

\author{
Loredana Maiuolo *, Vincenzo Algieri *(D), Fabrizio Olivito * and Antonio De Nino( \\ Dipartimento di Chimica e Tecnologie Chimiche, Via P. Bucci, cubo 12C, Università della Calabria, 87036 \\ Rende (CS), Italy; denino@unical.it \\ * Correspondence: maiuolo@unical.it (L.M.); vincenzo.algieri@unical.it (V.A.); fabrizio.olivito@unical.it (F.O.); \\ Tel.: +39-0984-492853 (L.M.)
}

Received: 15 November 2019; Accepted: 27 December 2019; Published: 1 January 2020

\begin{abstract}
The use of eco-compatible synthetic procedures in organic reactions and, in particular, in 1,3-dipolar cycloaddition reactions, has recently received a great deal of attention and considerable progress has been achieved in this area in the last years. This review summarizes the approaches currently employed to synthesize heterocyclic compounds by catalyzed 1,3-dipolar cycloadditions in green solvents in the last six years. Our choice to do a selection of the literature from 2014 to 2019 was made considering the absence of a recent review about this period, to our knowledge. Several examples to construct heterocycles by 1,3-dipolar cycloadditions will be discussed in this work subdivided in function of the most important class of non-conventional and green solvents, i.e., ionic liquids (ILs), deep eutectic solvents (DES), and water.
\end{abstract}

Keywords: 1,3-dipolar cycloadditions; ionic liquids; deep eutectic solvents; Lewis acids; on-water reactions

\section{Introduction}

The reaction of 1,3-dipolar cycloaddition (1,3-DC) is a powerful synthetic approach for the formation of a variety of heterocycles, very important scaffolds in many biological active compounds [1]. Nitrones, azides, and azomethine ylides are only some of the 1,3-dipoles employed to build variable heterocyclic structures. For example, the cycloaddition of nitrones with olefins is one of the most versatile protocol for the construction of isoxazolidines, $\mathrm{N}, \mathrm{O}$-heterocycles with three new contiguous stereocenters [2]. These type of reactions are tightly tied to its selectivity: Regioselectivity, diastereoselectivity, and enantioselectivity can be predicted through considerations of steric and electronic factors, but most significantly through the frontier molecular orbital (FMO) theory [3].

The toxic properties of many traditional solvents and the drastic reaction conditions of these reactions have prompted the scientists in directing their attention to develop new eco-compatible synthetic procedure in non-conventional, green solvents [4]. Ionic liquids (ILs), deep eutectic solvents (DES), and water represent, at this moment, some alternatives for environmentally unfriendly classical solvents [5]. The use of transition metal catalysts as the classical Lewis acids has surely aimed the 1,3-dipolar cycloadditions at major selectivity [6], even if at one time organocatalyzed cycloadditions have been developed, performing highly selective reactions [7]. On the other hand, ILs and DES are always of greatest interest for their catalytic properties, as well as their easy preparation $[8,9]$.

The goal of this review is to highlight synthetic methodologies to construct $\mathrm{N}, \mathrm{O}$-heterocycles by 1,3-dipolar cycloaddition, employing appropriate catalysis in eco-friendly reaction conditions. The review is organized on the basis of catalyzed 1,3-DC reactions conducted prevalently in ionic liquids, deep eutectic solvents, and water, and collects the latest developments that we have decided to restrict in the last six years, making a selection of the literature from 2014 to 2019. In fact, in the 
literature, recent reviews on this interest area are reported, but they prevalently collect works before the period considered by us $[10,11]$.

\section{1,3-DC in Ionic Liquids}

\subsection{Ionic Liquids}

Ionic liquids (ILs) are defined as salts with melting point below the boiling point of water and they are widely recognized as green solvents in many organic reactions for their properties [12]. Generally, they consist of an organic cation and an inorganic anion, and their different combination has a high impact on polarity, hydrophilicity/hydrophobicity, and physical and chemical properties of the ionic liquid, including their melting points. Typically, the anions are inorganic and include $\left[\mathrm{PF}_{6}\right]^{-}$, $\left[\mathrm{BF}_{4}\right]^{-},\left[\mathrm{CF}_{3} \mathrm{SO}_{3}\right]^{-}$, and $\left[\left(\mathrm{CF}_{3} \mathrm{SO}_{2}\right)_{2} \mathrm{~N}\right]^{-}$, while the organic cationic portion is generally constituted from asymmetric ammonium or phopshonium salts or heterocycles, such as 1,3-dialkylimidazolium 1, 1-alkylpyridinium 2, and 1,1-dialkylpyrolidinium salts 3 (Figure 1) [13].

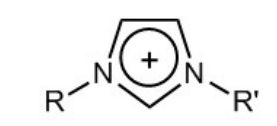

1,3-dialkylimidazolium $\left[\mathrm{C}_{\mathrm{n}} \mathrm{C}_{\mathrm{m}}\right]^{+}$

1

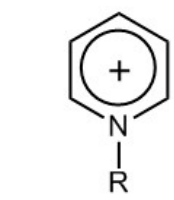

1-alkylpyridinium

$\left[\mathrm{C}_{\mathrm{n}} \mathrm{Pr}\right]^{+}$

2

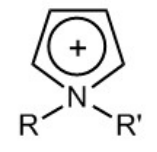

1,1-dialkylpyrolidinium

$\left[\mathrm{C}_{\mathrm{n}} \mathrm{C}_{\mathrm{m}}\right]^{+}$

3

$\mathrm{R}=\mathrm{R}^{\prime}=$ Alkyl or Aryl groups

Figure 1. Some common cations used for ionic liquids [13].

In general, the ILs (1) are colorless liquids with low viscosity; (2) exhibit very low vapor pressures and, for this reason, are non-volatile; (3) are often insoluble with various organic solvents, making biphasic systems possible; (4) being composed of two parts of different nature, they induce a major synthetic flexibility than classical organic solvents. Moreover, the ionic liquids may have a so-called ionic self-assembly (ISA) structure due to noncovalent electrostatic interactions as the primary driving force and hydrophobic interactions and $\pi-\pi$ interactions as secondary driving forces [14]. Therefore, the combination of cations and anions of ILs highly organized in hierarchical superstructures might firmly hold the reagents, favoring their alignment and improving their interaction [15]. Based on their properties, they have recently received a good deal of attention as alternative solvents in a number of reactions $[16,17]$. Moreover, depending upon the functional group linked to cation and/or anion of ionic liquid, it may be an acid or basic organocatalyst [4]. In addition, it is worth noticing that it has been recently found that ionic liquids can be easily prepared by simply mixing two opportunely chosen amphiphilic liquids [18]. In this case, further additional properties can arise, like anysotropical self-assembly [19,20], response to an external magnetic field [21], enhanced proton conductivity [22], and enhanced capability of salt solubilization [23], which can open a wide scenario of new and promising applications.

\subsubsection{Synthesis of Spirocyclic Compounds}

Spirooxindole derivatives have a privileged hetereocyclic core that confers them substantial biological activity, such as antimicrobial, anticancer, inhibitorial of MDM2-p53 interaction, and so on [24-26]. In 2015, an efficient, simple, and rapid one-pot synthesis of dispirooxindolo-pyrrolidines $\mathbf{8 a}-\mathbf{f}$ and $\mathbf{9 a}-\mathbf{f}$ via a three-component 1,3-dipolar cycloaddition in ionic liquid media was proposed from Arumugam et al. (Scheme 1) [27]. 


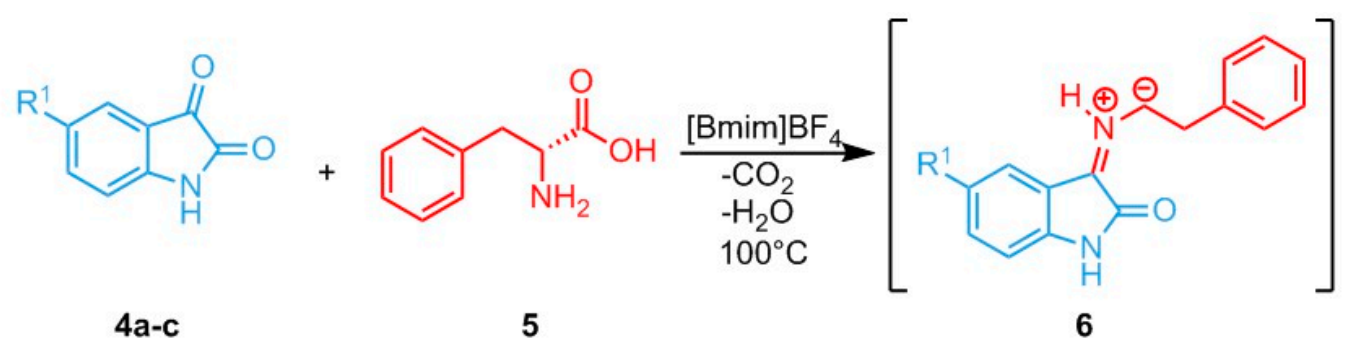

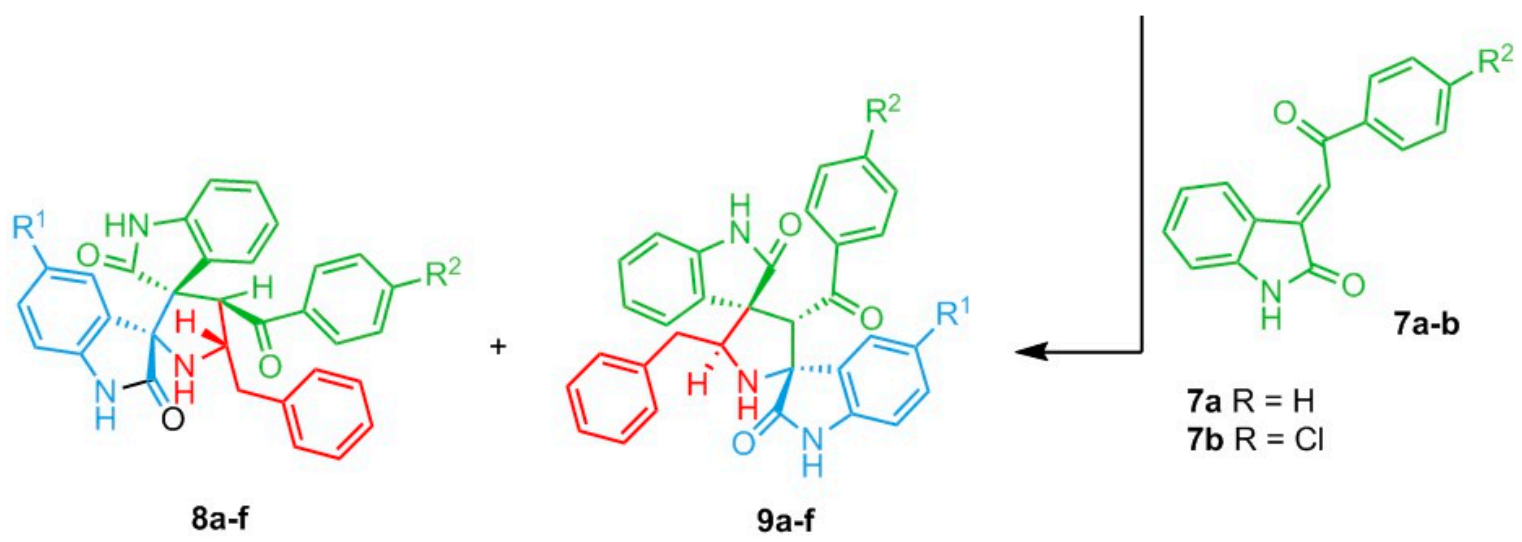

\begin{tabular}{cccccc}
\hline Derivatives & $\mathbf{R}^{\mathbf{1}}$ & $\mathbf{R}^{\mathbf{2}}$ & Yield of $\mathbf{8}(\mathbf{\%})$ & Yield of 9 (\%) & Regioselectivity (8/9) \\
\hline $\mathbf{a}$ & $\mathrm{H}$ & $\mathrm{Cl}$ & 77 & 7 & $91 / 9$ \\
$\mathbf{b}$ & $\mathrm{H}$ & $\mathrm{H}$ & 70 & 5 & $85 / 15$ \\
$\mathbf{c}$ & $\mathrm{Cl}$ & $\mathrm{Cl}$ & 75 & 6 & $89 / 11$ \\
$\mathbf{d}$ & $\mathrm{Cl}$ & $\mathrm{H}$ & 73 & 5 & $90 / 10$ \\
$\mathbf{e}$ & $\mathrm{NO}_{2}$ & $\mathrm{Cl}$ & 72 & 5 & $88 / 12$ \\
$\mathbf{f}$ & $\mathrm{NO}_{2}$ & $\mathrm{H}$ & 71 & 5 & $87 / 13$ \\
\hline
\end{tabular}

Scheme 1. One-pot synthesis of dispirooxindolo-pyrrolidines $\mathbf{8 a}-\mathbf{f}$ and $\mathbf{9 a}-\mathbf{f}$ by a three-component 1,3-dipolar cycloaddition [27].

The reaction was performed in the presence of $\left[\mathrm{bmim}^{-}\left[\mathrm{BF}_{4}\right]\right.$ between an azomethine ylides 6 as dipole, generated in situ by decarboxylative condensation of isatin derivatives $4 \mathbf{a}-\mathbf{c}$ and L-phenylalanine $\mathbf{5}$, and (E)-2-oxoindolino-3-ylidene acetophenones $\mathbf{7 a - b}$ as dipolarophile.

An initial screening to optimize the reaction conditions was performed using common organic solvents (i.e., $\mathrm{MeOH}, \mathrm{EtOH}$, Dioxane, Dioxane/ $\mathrm{MeOH}$ ) or ionic liquids ([bmim] Br, [bmim][BF4]) in the absence or presence of a Lewis acid $\left(\mathrm{CuI}\right.$ or $\left.\mathrm{Zn}(\mathrm{OTf})_{2}\right)$. At the end, the $[\mathrm{bmim}]\left[\mathrm{BF}_{4}\right]$ was selected as better IL. In all cases, the final products were obtained with quantitative yield, high regio- and diasteoselectivity, and short reaction time, recycling the ionic liquid and reusing it for five runs without loss of activity. The presence of Lewis acid catalyst did not improve the trend of the reaction, reducing significantly the yield and the selectivity. Therefore, a plausible catalysis of ionic liquid was invoked from the authors that supposed a catalytic performace of $[\mathrm{bmim}]\left[\mathrm{BF}_{4}\right]$ in various studies of the reaction.

A series of spirooxindolepyrrolidines $\mathbf{1 4}$ as potential inhibitors of cholinesterase were synthesized by Kumar et al., using a 1,3-dipolar cycloaddition between azomethine ylide dipole, formed with various 1,2-diketones (11 or 15) and triptophan 12, and arylmethylidene inden-1-ones 10 as dipolarophile in ionic liquid media (Scheme 2) [28]. 
<smiles>COc1cc2c(cc1OC)C(=O)/C(=C/Br)C2</smiles>

10

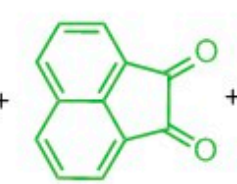

11<smiles>NC(Cc1c[nH]c2ccccc12)C(=O)O</smiles>

12

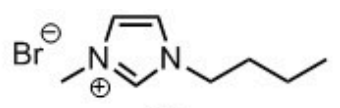

13

$100^{\circ} \mathrm{C}, 1 \mathrm{~h}$

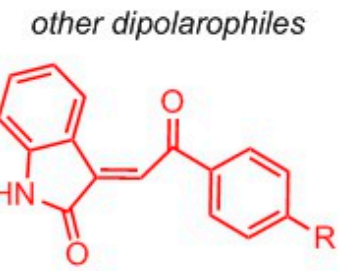

15

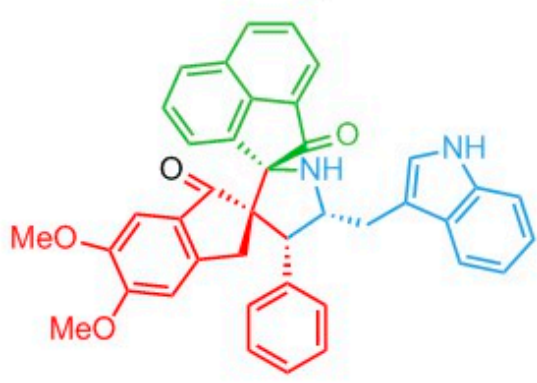

$14(76-88 \%)$

$\mathrm{R}=\mathrm{H}, \mathrm{CH}_{3}, \mathrm{CH}_{3} \mathrm{O}, \mathrm{Cl}, \mathrm{NO}_{2}$

$\mathrm{Ar}=\mathrm{Ph}, 2-\mathrm{CH}_{3}-\mathrm{Ph}, 2-\mathrm{CH}_{3} \mathrm{O}-\mathrm{Ph}, 2-\mathrm{Cl}-\mathrm{Ph}, 3-\mathrm{CH}_{3} \mathrm{O}-\mathrm{Ph}, 3-\mathrm{NO}_{2}-\mathrm{Ph}, 4-\mathrm{CH}_{3}-\mathrm{Ph}, 4-\mathrm{CH}_{3} \mathrm{O}-\mathrm{Ph}, 4-\mathrm{Cl}$

Scheme 2. Synthesis of spirooxindolepyrrolidines 14 as potential inhibitors of cholinesterase [28].

The reactions were conducted in 1-butyl-3-methylimidazolium bromide ([bmim]Br) at $100{ }^{\circ} \mathrm{C}$ in low reaction time isolating the final products in $76 \%-88 \%$ yield.

Spiroisoxazolidines $[29,30]$ are found to have a relevant biological importance for various human diseases, inhibiting various viruses, i.e., 6 HIV-1 [31] and, more recently, the MDM2-p53 interaction [32].

Moreover, the introduction of halogens and, in particular, of fluorine atoms on the skeleton of organic compounds may amplify their stability, lipophilicity, and biological activities [33]. For this reason, in 2018, Chakraborty and his research group performed an efficient synthetic protocol to isolate substituted spiroisoxazolidines $\mathbf{2 1}$, some of which halo-substitued, in [bmim]BF 4 as ionic liquid that favored low reaction time, room temperature condition, and high yields (Scheme 3) [34].

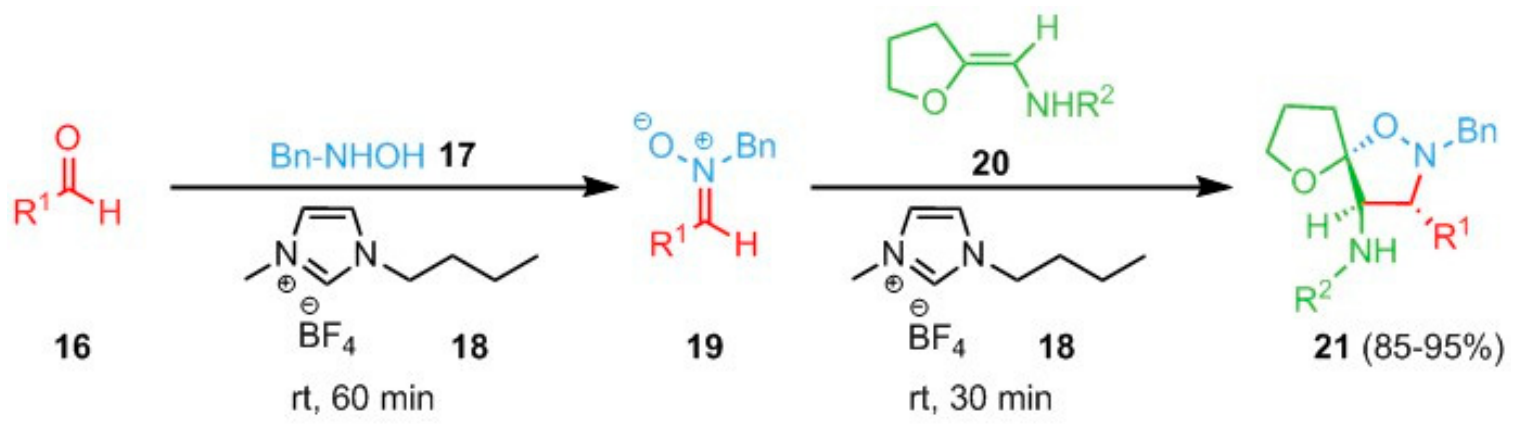

$$
\begin{aligned}
& \mathrm{R}^{1}=\mathrm{C}_{6} \mathrm{H}_{5} ; 4-\mathrm{F}-\mathrm{C}_{6} \mathrm{H}_{5} ; 2-\mathrm{F}-\mathrm{C}_{6} \mathrm{H}_{5} ; \mathrm{C}_{6} \mathrm{~F}_{5} ; 4-\mathrm{CF}_{3}-\mathrm{C}_{6} \mathrm{H}_{5} ; \mathrm{NH}_{2} ; \mathrm{CHCl}\left(\mathrm{CH}_{2}\right)_{3} \mathrm{OH} \\
& \mathrm{R}^{2}=\mathrm{C}_{6} \mathrm{H}_{5} ; 4-\mathrm{OH}-\mathrm{C}_{6} \mathrm{H}_{4} ; 2-\mathrm{OH}-\mathrm{C}_{6} \mathrm{H}_{4} ; 4-\mathrm{Br}_{-}-\mathrm{C}_{6} \mathrm{H}_{4} ; 4-\mathrm{NO}_{2}-\mathrm{C}_{6} \mathrm{H}_{4} ; 2-\mathrm{NO}_{2}-\mathrm{C}_{6} \mathrm{H}_{4} ; \mathrm{CH}_{3} ; \mathrm{Bn}
\end{aligned}
$$

Scheme 3. Synthesis of substituted halo-substitued spiroisoxazolidines 21 [34].

Several butylmethylimidazolium-based ionic liquid [bmim]X with different anion $\left(\mathrm{X}^{-} \mathrm{PF}_{6}{ }^{-}\right.$, $\left.\mathrm{Br}^{-}, \mathrm{BF}_{4}^{-}\right)$were tested and $[\mathrm{bmim}] \mathrm{BF}_{4}$ gave the best performance in terms of higher yield and lower reaction time. The same reactions in absence of ionic liquid showed a remarkable reduction in reaction yield, demonstrating a probable role of IL as catalyst as well as solvent. 


\subsubsection{Synthesis of Triazole Derivatives}

The 1,2,3-triazole substrates represent a significant class of nitrogen compounds with numerous biological properties, such as antibacterial, anticancer, antivirus, and antitubercolosis [35,36]. Moreover, they have found industrial applications as dyes, agrochemicals, photostabilizers, etc. For these reasons, in recent years, synthetic procedures alternative to classical synthesis of substituted triazoles were proposed. In particular, in 2018, an efficient and reusable homogeneous catalyst consisting of ionic liquid/iron(III) chloride was applied in synthesis of 1,5-disubstituted 1,2,3-triazoles 24a-n, isolating the final products in considerable yields, high regioselectivity, furnishing only the 1,5-disubstituted substrate, and very short reaction time (Scheme 4) [37].

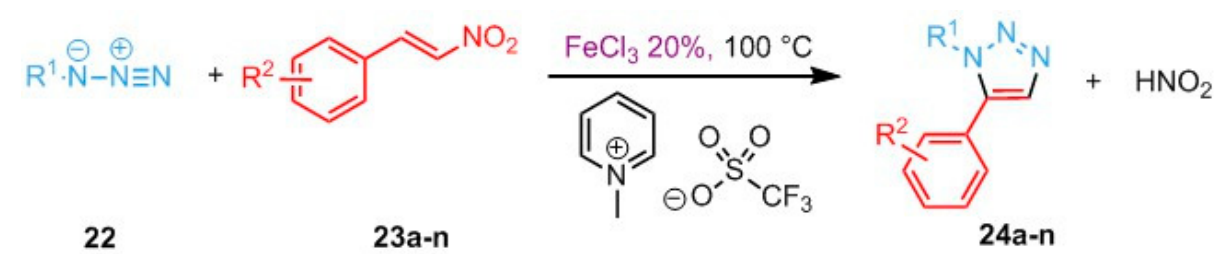

\begin{tabular}{cccc}
\hline $\mathbf{R}^{\mathbf{1}}$ & $\mathbf{R}^{\mathbf{2}}$ & Product $\mathbf{2 4}$ & Yield (\%) \\
\hline $\mathrm{Bn}$ & $\mathrm{H}$ & $\mathbf{a}$ & 95 \\
$\mathrm{Bn}$ & $2-\mathrm{Cl}$ & $\mathbf{b}$ & 85 \\
$\mathrm{Bn}$ & $3-\mathrm{Cl}$ & $\mathbf{c}$ & 84 \\
$\mathrm{Bn}$ & $4-\mathrm{Cl}$ & $\mathbf{d}$ & 86 \\
$\mathrm{Bn}$ & $4-\mathrm{MeO}$ & $\mathbf{e}$ & 93 \\
$\mathrm{Bn}$ & $4-\mathrm{Me}$ & $\mathbf{f}$ & 92 \\
$\mathrm{Bn}$ & $2-\mathrm{NO}_{2}$ & $\mathbf{g}$ & 81 \\
$\mathrm{Ph}$ & $\mathrm{H}$ & $\mathbf{h}$ & 91 \\
$\mathrm{Ph}$ & $2-\mathrm{Cl}$ & $\mathbf{i}$ & 87 \\
$\mathrm{Ph}$ & $3-\mathrm{Cl}$ & $\mathbf{j}$ & 93 \\
$\mathrm{Ph}$ & $4-\mathrm{Cl}$ & $\mathbf{k}$ & 92 \\
$\mathrm{Ph}$ & $4-\mathrm{MeO}$ & $\mathbf{1}$ & 92 \\
$\mathrm{Ph}$ & $4-\mathrm{Me}$ & $\mathbf{m}$ & 96 \\
$\mathrm{Ph}$ & $2-\mathrm{NO} 2$ & $\mathbf{n}$ & 95 \\
\hline
\end{tabular}

Scheme 4. Synthesis of 1,5-disubstituted 1,2,3-triazoles $\mathbf{2 4 a - n}$ by ionic liquid/iron(III) chloride system [37].

The synthetic process involves an eliminative azide-olefin cycloaddition (EAOC) reaction between nitroolefins 23a-n, excellent dipolarophiles to synthesize triazoles due to electron-withdrawing nitro group, and substituted azides $\mathbf{2 2}$ as dipoles. Initial experiments were performed on a model reaction to optimize the reaction conditions, mainly varying the employed Lewis acid and the ionic liquid. At the end, the best catalytic system was made up of 1-methyl pyridinium trifluoromethanesulfonate [mPy]OTf and $\mathrm{FeCl}_{3}$ and the investigation was extended to various arylnitroolefins and benzylor phenylazides. Theoretical calculations indicated that an asynchronous concerted 1,3-dipolar cycloaddition reaction might be involved to form the instable triazoline intermediates that afforded the final substituted triazoles by an eliminative process.

Successively, the same authors suggested an alternative method to synthesize 1,5-disubstituted 1,2,3-triazoles using the catalytic system [mPy]OTf/ $\mathrm{H}_{2} \mathrm{O} / \mathrm{Er}(\mathrm{OTf})_{3}$ in which the anionic part of ionic liquid matches Lewis acid's [38]. This proposed approach led to the reduction of the amount of employed catalyst without loss of regioselectivity, the increase in reaction yield, and a great recycle of ionic liquid. The role of all three actors of catalytic system was explicated, proposing a favorite alignment of cation and anion of IL that trap the reagents, by promoting the HOMO dipole/LUMO dipolarophile interaction (Figure 2). 


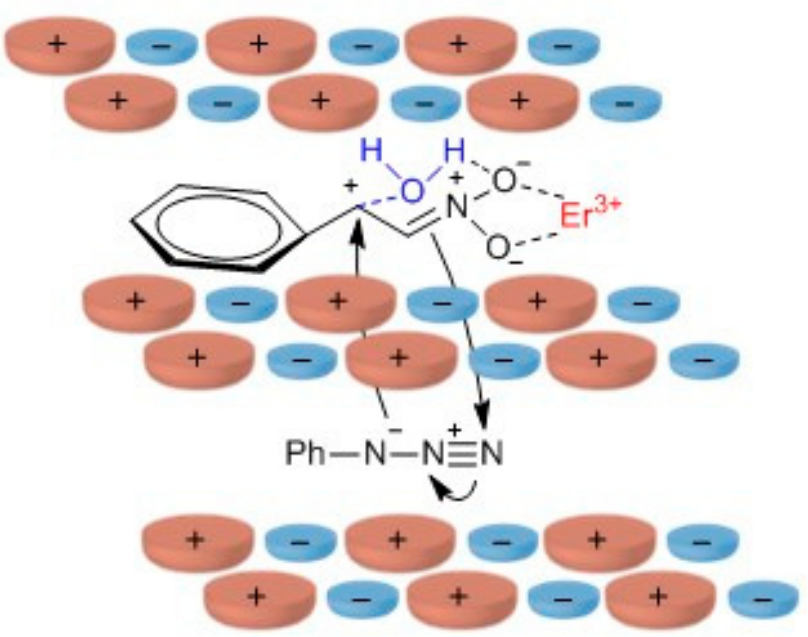

Figure 2. Favorite alignment of dipole and dipolarophile induced by hierarchical superstructures of ionic liquid [38].

Finally, a regioselective synthesis of 1,4,5-trisubstituted-1,2,3-triazoles $\mathbf{2 7 a - p}$ water promotion was realized in [mPy] OTf as ionic liquid, starting from arylazides $\mathbf{2 5}$ and enaminones $\mathbf{2 6}$ in base media by a classical 1,3-dipolar cycloddition (Scheme 5) [39].

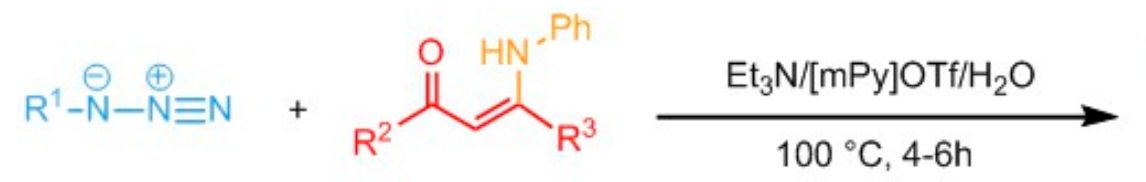

25 26<smiles>[R]C(=O)c1nnn([R])c1[R]</smiles>

27a-p

\begin{tabular}{ccccc}
\hline $\mathbf{R}^{\mathbf{1}}$ & $\mathbf{R}^{\mathbf{2}}$ & $\mathbf{R}^{\mathbf{3}}$ & Product 27 & Yield (\%) \\
\hline $\mathrm{Ph}$ & $\mathrm{Me}$ & $\mathrm{Me}$ & $\mathbf{a}$ & 84 \\
$\mathrm{Ph}$ & $\mathrm{Et}$ & $\mathrm{Et}$ & $\mathbf{b}$ & 82 \\
$\mathrm{Bn}$ & $\mathrm{Ph}$ & $\mathrm{Me}$ & $\mathbf{c}$ & 82 \\
$\mathrm{Ph}$ & $\mathrm{Ph}$ & $\mathrm{Me}$ & $\mathbf{d}$ & 84 \\
$\mathrm{Bn}$ & $\mathrm{Me}$ & $\mathrm{Me}$ & $\mathbf{e}$ & 85 \\
3-F-Ph & $\mathrm{Me}$ & $\mathrm{Me}$ & $\mathbf{f}$ & 85 \\
3-F-Ph & $\mathrm{Ph}$ & $\mathrm{Me}$ & $\mathbf{g}$ & 81 \\
4-NO2-Ph & $\mathrm{Me}$ & $\mathrm{Me}$ & $\mathbf{h}$ & 82 \\
4-NO2-Ph & $\mathrm{Ph}$ & $\mathrm{Me}$ & $\mathbf{i}$ & 84 \\
4-Cl-Ph & $\mathrm{Me}$ & $\mathrm{Me}$ & $\mathbf{j}$ & 83 \\
4-Cl-Ph & $\mathrm{Ph}$ & $\mathrm{Me}$ & $\mathbf{k}$ & 82 \\
4-Me-Ph & $\mathrm{Me}$ & $\mathrm{Me}$ & $\mathbf{1}$ & 85 \\
4-Me-Ph & $\mathrm{Ph}$ & $\mathrm{Me}$ & $\mathbf{m}$ & 84 \\
4-MeO-Ph & $\mathrm{Me}$ & $\mathrm{Me}$ & $\mathbf{n}$ & 85 \\
4-MeO-Ph & $\mathrm{Ph}$ & $\mathrm{Me}$ & $\mathbf{o}$ & 81 \\
$\mathrm{Ph}$ & $\mathrm{Ph}$ & $\mathrm{Ph}$ & $\mathbf{p}$ & 70 \\
\hline
\end{tabular}

Scheme 5. Regioselective water-promoted synthesis of 1,4,5-trisubstituted-1,2,3-triazoles 27a-p [39].

The complete regioselectivity of the reaction is found on the initial regioselectivity of triazoline formation that determines the position of carbonyl group always at C-4. DFT calculations proposed a cascade mechanism consisting of a typical Huisgen's concerted asynchronous 1,3-dipolar cycloaddition followed by an elimination step through a retro-aza-Michael with loss of aniline. 


\subsubsection{Synthesis of N-Fused Heterocycles}

$N$-fused heterocycles have versatile structural units that constitute an important class of molecules of great interest in many research fields of medicines and pharmaceuticals.

In 2015, Kumar and co-workers realized new polycyclic ring systems 30a-m and 32a-m by a three-component, 1,3-dipole generation-cycloaddition-annulation domino sequence in [ $\mathrm{bmim}] \mathrm{Br}$ contemporary as solvent and catalyst (Scheme 6) [40].

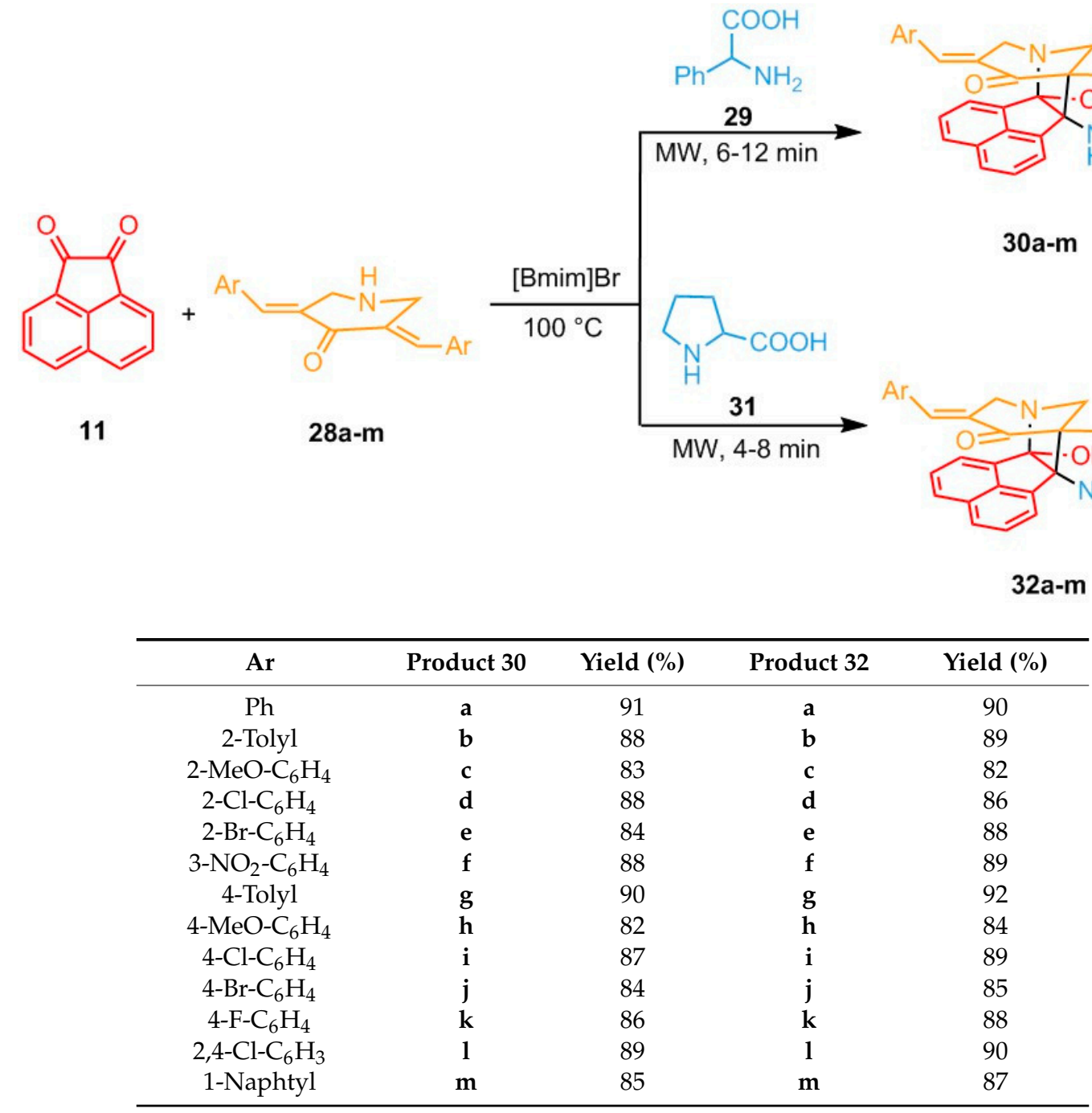

Scheme 6. Synthesis of piperidone derivatives $\mathbf{3 0 a}-\mathbf{m}$ and $\mathbf{3 2} \mathbf{a}-\mathbf{m}$ with cage-like cavities [40].

The reaction provided for the use of substituted bis-dipolarophiles $\mathbf{2 8 a} \mathbf{a}-\mathbf{m}$ as starting materials that were reacted with azomethine ylides generated in situ from acenaphthenequinone $\mathbf{1 1}$ and $\alpha$-amino acids, such as phenylglicine $\mathbf{2 9}$ and proline 31 . The proposed cascade process produced a set of piperidone derivatives $\mathbf{3 0 a}-\mathbf{m}$ and $\mathbf{3 2 a}-\mathbf{m}$ with cage-like cavities, important for biological applications, in high yields and very short reaction time. The authors specified the catalytic role of ionic liquid that is involved at several steps, among which the initial azomethine ylide form (Scheme 7). 


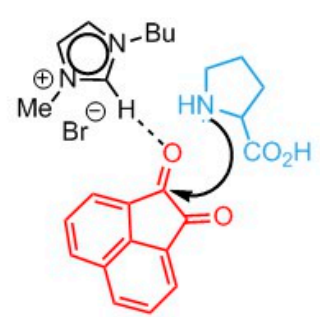

33

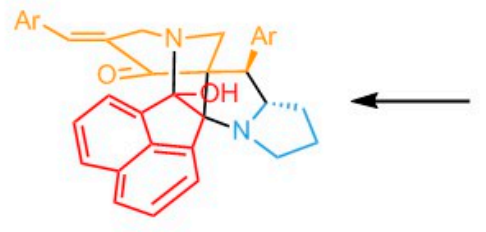

32

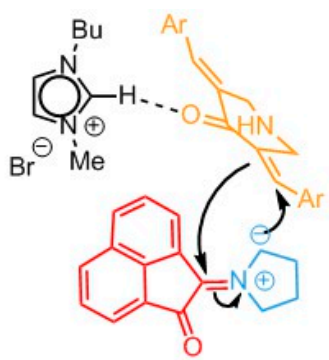

34

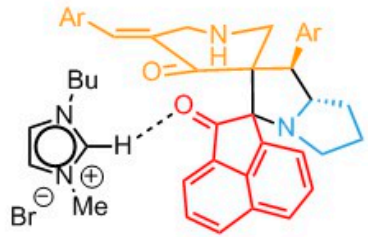

35

$\mathrm{Ar}=\mathrm{Ph}, 2-\mathrm{Tolyl}, 2-\mathrm{MeO}-\mathrm{C}_{6} \mathrm{H}_{4}, 2-\mathrm{Cl}-\mathrm{C}_{6} \mathrm{H}_{4}, 2-\mathrm{Br}-\mathrm{C}_{6} \mathrm{H}_{4}, 3-\mathrm{NO}_{2}-\mathrm{C}_{6} \mathrm{H}_{4}$, 4-Tolyl, 4$\mathrm{MeO}-\mathrm{C}_{6} \mathrm{H}_{4}, 4-\mathrm{Cl}-\mathrm{C}_{6} \mathrm{H}_{4}, 4-\mathrm{Br}-\mathrm{C}_{6} \mathrm{H}_{4}, 4-\mathrm{F}-\mathrm{C}_{6} \mathrm{H}_{4}, 2,4-\mathrm{Cl}-\mathrm{C}_{6} \mathrm{H}_{3}, 1-\mathrm{Naphtyl}$

Scheme 7. Plausible mechanism for the formation of heptacyclic cage compounds [40].

In the same year, Parmar et al. generated a new class of bioactive heterocycles 42-46 with $N$-fused indoles and $N$-fused isoquinolines inserted into a molecular assembly by 1,3-dipolar cycloaddtion reaction between the $\mathrm{N}$-allyl-C-aldoderivatives of 3-chloroindole 36 and various amines 39-41, using trietylammonium acetate (TEAA) as inexpensive ionic liquid (Scheme 8) [41].

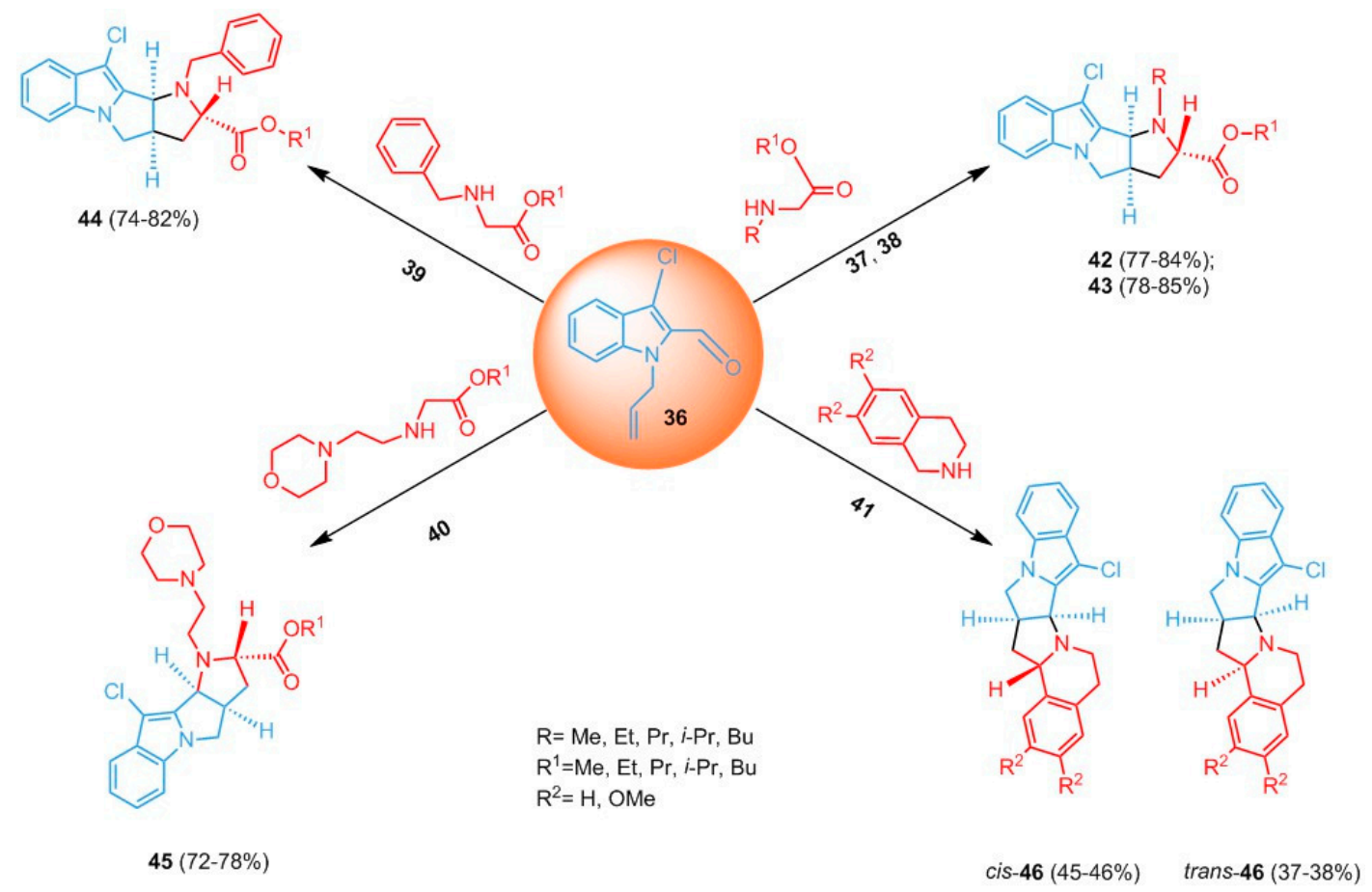

Scheme 8. Synthesis of heterocycles $\mathbf{4 2 - 4 6}$ with $N$-fused indoles and $N$-fused isoquinolines [41]. 
Initially, the researchers optimized the reaction conditions, performing a model reaction in many classical solvents, varying the reaction temperature and adding $\mathrm{Na}_{2} \mathrm{SO}_{4}$ as catalyst. Then, they abandoned the conventional way in favor of TEAA ionic liquid that had the double function of solvent and catalyst. A plausible mechanism was proposed about the stereochemistry of the reaction, studying the exo and endo attack of dipolarophile alkene and dipole azomethine ylide. NMR studies confirmed, as always, a cis-fusion between pyrrolidine rings, deriving from an endo transition state (Scheme 9).

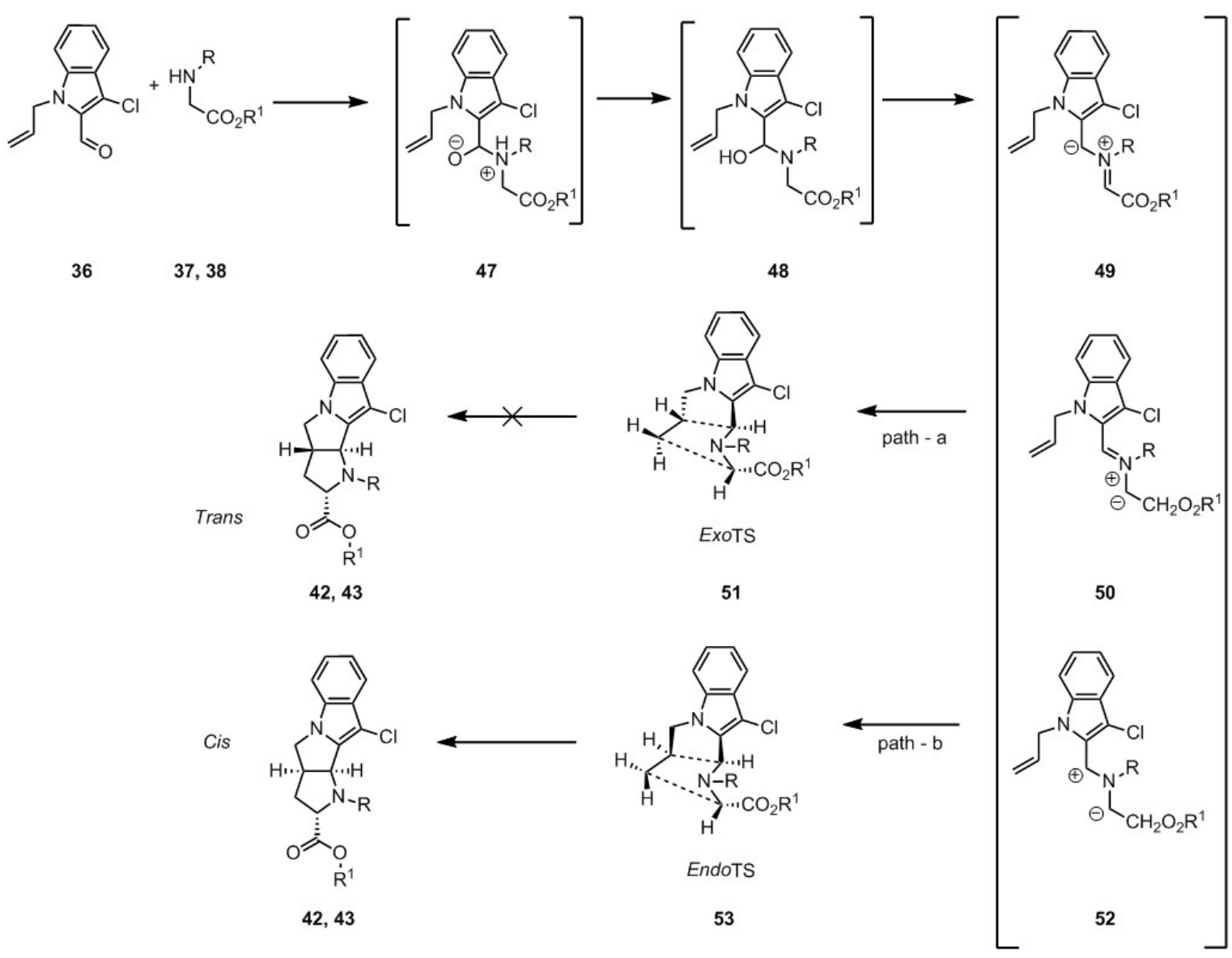

$R=M e, E t, \operatorname{Pr}, i-\operatorname{Pr}, B u ; R^{1}=M e, E t, \operatorname{Pr}, i-\operatorname{Pr}, B u$

Scheme 9. Stereochemistry of synthesis of $N$-fused indoles and $N$-fused isoquinolines [41].

Finally, the antiproliferative activity of the isolated substrates was tested against some tumor cell lines, obtaining results comparable to used standard drugs.

\subsubsection{Synthesis of Isoxazolines and Isoxazolidines}

A versatile synthesis of isoxazolines $59 a-c$ and isoxazolidines $60 a-c$ was proposed from Chakraborty and co-workers in alternative to the classical methodology $\left(\mathrm{CH}_{2} \mathrm{Cl}_{2}\right.$, as solvent, $40-60{ }^{\circ} \mathrm{C}$, $42 \mathrm{~h}$ ), to prepare cycloadducts deriving by 1,3-dipolar cycloaddition between dihydropyran derived nitrones $\mathbf{5 6}$ and alkynes $\mathbf{5 7}$ or alkenes $\mathbf{5 8}$ in ionic liquids (Scheme 10) [42].

The reactions were conducted both in conventional solvent and in ionic liquid, noticing in the latter case a very good increase of yield up to $91 \%$, a remarkable reduction of reaction time from hours to minutes and a superior stereoselectivity in isoxazolidine formation. In fact, the cycloadditions were oriented towards a mixture of endo and exo-isomers, favoring the endo-diastereomers. The authors carried out a screening of various bmim-based-ILs with varying anions $\left(\mathrm{X}=\mathrm{PF}_{6}^{-}, \mathrm{Br}^{-}, \mathrm{BF}_{4}^{-}\right)$, electing $[\mathrm{bmim}] \mathrm{BF}_{4}$ as the best solvent. Moreover, they performed the reactions under neat conditions, without 
[bmim $] \mathrm{BF}_{4}$, also demonstrating catalytic activity of IL. Finally, the [bmim] $\mathrm{BF}_{4}$ was recuperated by washing with diethyl ether, drying at $80^{\circ} \mathrm{C}$ under reduced pressure, and reusing up to five times without loss of activity nor selectivity.

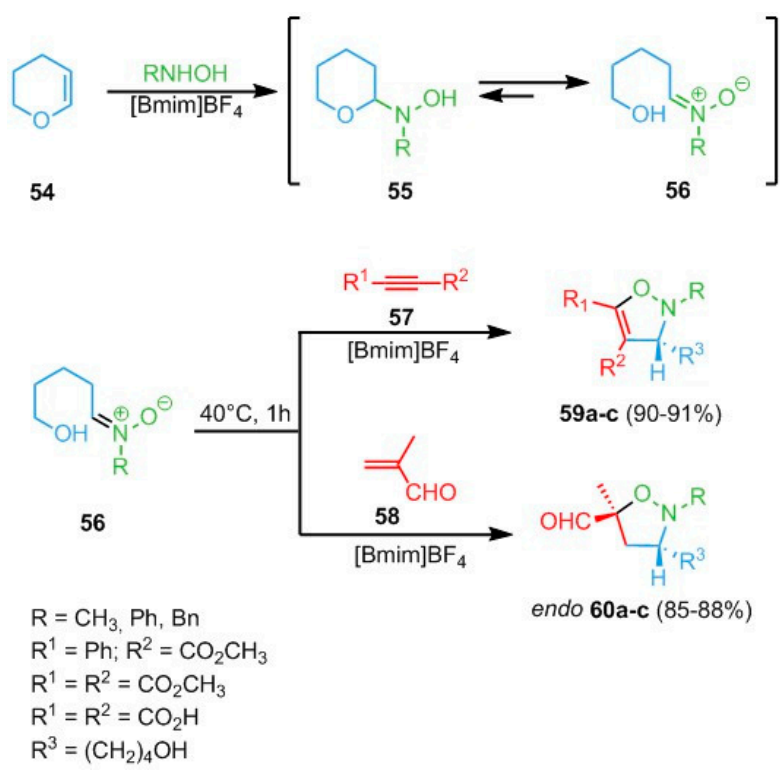

Scheme 10. Synthesis of isoxazolines $59 a-c$ and isoxazolidines $60 a-c$, starting from dihydropyran derived nitrones 56 and alkynes 57 or alkenes 58 [42].

In 2014, an enantioselective version of synthesis of isoxazolidines 64 and 65 was proposed from Nie et al., employing tetraarylphosphonium supported chiral imidazolidinones 63 as catalyst in 1,3-dipolar cycloadditions of $\alpha, \beta$-unsaturated aldehydes with nitrones (Scheme 11) [43].

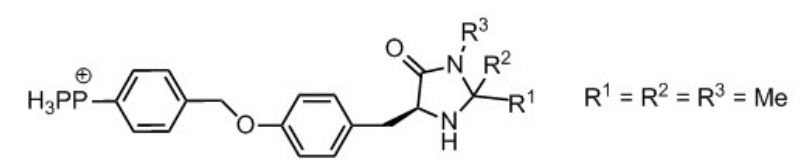

63

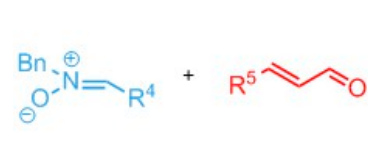

61

62

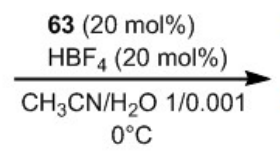

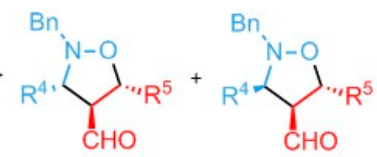

$\begin{array}{cc}64 & 65 \\ \text { endo } & \text { exo }\end{array}$

\begin{tabular}{cccccc}
\hline $\mathbf{R}^{\mathbf{4}}$ & $\mathbf{R}^{\mathbf{5}}$ & Product & Yield (\%) & endo/exo & Endo ee $\mathbf{( \% )}$ \\
\hline $\mathrm{Ph}$ & $\mathrm{Me}$ & $\mathbf{6 4 a + 6 5 a}$ & $\mathbf{8 9}$ & $94 / 6$ & 94 \\
$4-\mathrm{ClPh}$ & $\mathrm{Me}$ & $\mathbf{6 4 b}+\mathbf{6 5} \mathbf{b}$ & $\mathbf{7 2}$ & $90 / 10$ & 90 \\
$4-\mathrm{OMePh}$ & $\mathrm{Me}$ & $\mathbf{6 4 c}+\mathbf{6 5 c}$ & $\mathbf{7 8}$ & $93 / 7$ & 88 \\
$4-\mathrm{MePh}$ & $\mathrm{Me}$ & $\mathbf{6 4 d}+\mathbf{6 5 d}$ & $\mathbf{7 9}$ & $91 / 9$ & 85 \\
2-Naphthyl & $\mathrm{Me}$ & $\mathbf{6 4 e}+\mathbf{6 5 e}$ & $\mathbf{8 1}$ & $90 / 10$ & 92 \\
$\mathrm{Ph}$ & $n-\mathrm{Pr}$ & $\mathbf{6 4 f}+\mathbf{6 5 f}$ & $\mathbf{7 2}$ & $94 / 6$ & 97 \\
$\mathrm{Ph}$ & $\mathrm{H}$ & $\mathbf{6 4 g}+\mathbf{6 5 g}$ & $\mathbf{7 7}$ & $94 / 6$ & 88 \\
\hline
\end{tabular}

Scheme 11. Enantioselective synthesis of isoxazolidines 64 and 65 by catalysis of tetraarylphosphonium supported chiral imidazolidinones 63 [43].

More specifically, the tetraarylphosphonium-supported chiral imidazolidinones were obtained by immobilizing MacMillan-type imidazolidinone catalysts onto ionic liquid [44]. 
The model reaction between N-benzyl-C-phenyl nitrone and E-crotonaldehyde was chosen to establish the best reaction conditions, performing the final products (64a and 65a) in high yield and excellent diastereo- and enantioselectivity (yield: $89 \%$; endo/exo ratio: 94/6; endo ee: $94 \%$ ). The choice of the solvent was crucial for the reaction outcome, electing, at the end, the system $\mathrm{CH}_{3} \mathrm{NO}_{2} / \mathrm{H}_{2} \mathrm{O}$ with the presence of $\mathrm{HBF}_{4}$ as co-catalyst. Variation of temperature and reaction time was also investigated, verifying that lower temperature $\left(0{ }^{\circ} \mathrm{C}\right)$ favors a higher stereoselectivity. Then, the reaction was extended to various starting materials, isolating the target products in $72 \%-89 \%$ yield and diastereoand enantioselectivity similar to model reaction results. In particular, the enantioselectivity obtained with the tetraarylphosphonium-supported chiral catalyst was compared with that found for MacMillan's imidazolidinone catalyst, observing results that were comparable. Finally, the authors recuperated the final products by simple precipitation and filtration, in this way recycling the catalyst that was reused for four cycles without loss of activity.

In 2015, Šebesta and co-workers tested nine different organocatalysts and six ionic liquids (Figure 3) in 1,3-dipolar cycloaddition of (Z)-N-benzylidene-1-phenylmethanamine oxide 66 with $\alpha, \beta$-unsaturated aldehydes 67a-f (Scheme 12) [45].<smiles></smiles>

$\left[\mathrm{Bmim}_{\mathrm{B}} \mathrm{BF}_{4}(\mathrm{IL}-\mathrm{I})\right.$

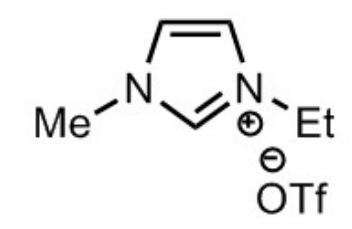

[Emim]OTf (IL-II)<smiles>[B-]N1C=CN(C)C([18O])=C1C</smiles>

[Bdmim]BF 4 (IL-III)<smiles>CCCCCC[N+]1(C)CCCC1</smiles>

IL-IV<smiles>C[N+](C)(C)[18OH]</smiles>

IL-V

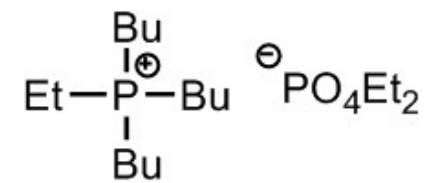<smiles>CN1C(=O)[C@H](Cc2ccccc2)NC1(C)C</smiles>

Cat-IV.HCI<smiles>CN1C(=O)[C@@H](Br)NC1(C)[OH2+]</smiles>

\section{Cat-IV-HOTf}

Figure 3. Six ionic liquids (commercial or prepared according to the literature [45]) and two of nine organocatalysts tested in 1,3-dipolar cycloaddition of (Z)-N-benzylidene-1-phenylmethanamine oxide with $\alpha, \beta$-unsaturated aldehydes [45]. 
<smiles>[O-][N+](=Cc1ccccc1)c1ccccc1</smiles>

66

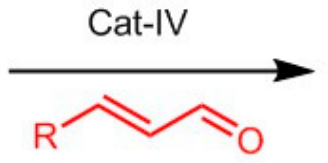

67a-f<smiles>[R]C1ON(Cc2ccccc2)[C@H]([PH2+])[C@@H]1CO</smiles>

endo-68a-c<smiles>[R]C1ON(Cc2ccccc2)C([Pb])[C@@H]1C=O</smiles>

exo-69a-c

\begin{tabular}{ccccc}
\hline Catalyst & Reaction Conditions & Yield (\%) & endo/exo & Enantiomeric Ratio of endo-68 \\
\hline Cat-IV HOTf & IL-I, $5{ }^{\circ} \mathrm{C}, 5 \mathrm{~d}$ & 20 & $92: 8$ & $56: 44$ \\
Cat-IV HCl & IL-I, 5 ${ }^{\circ} \mathrm{C}, 5 \mathrm{~d}$ & 21 & $79: 21$ & $91: 9$ \\
Cat-IV HCl & $\mathrm{IL}-\mathrm{I}, 40{ }^{\circ} \mathrm{C}, 3 \mathrm{~d}$ & 48 & $64: 36$ & $69: 31$ \\
Cat-IV HCl & $\mathrm{IL}-\mathrm{I}, \mathrm{H}_{2} \mathrm{O}, \mathrm{rt}, 3 \mathrm{~d}$ & 32 & $69: 31$ & $54: 46$ \\
Cat-IV HCl & IL-II, $\mathrm{H}_{2} \mathrm{O}, \mathrm{rt}, 3 \mathrm{~d}$ & 24 & $63: 37$ & $52: 48$ \\
Cat-IV HCl & IL-III, $\mathrm{H}_{2} \mathrm{O}, \mathrm{rt}, 3 \mathrm{~d}$ & 17 & $69: 31$ & $56: 44(90: 10)$ \\
Cat-IV HCl & IL-IV, $\mathrm{H}_{2} \mathrm{O}, \mathrm{rt}, 3 \mathrm{~d}$ & 47 & $83: 17$ & $75: 25(77: 23)$ \\
Cat-IV HCl & IL-V, $\mathrm{H}_{2} \mathrm{O}, \mathrm{rt}, 3 \mathrm{~d}$ & 51 & $76: 24$ & $66: 34(85: 15)$ \\
Cat-IV HCl & $\mathrm{IL}-\mathrm{VI}, \mathrm{H}_{2} \mathrm{O}, \mathrm{rt}, 3 \mathrm{~d}$ & 0 & - & - \\
\hline
\end{tabular}

Scheme 12. 1,3-dipolar cycloaddition of (Z)-N-benzylidene-1-phenylmethanamine oxide 66 with $\alpha, \beta$-unsaturated aldehydes $\mathbf{6 7 a - f}$ in presence of organocatalysts IV and ILs I-VI [45].

The reaction between crotonaldheyde $67 \mathrm{a}$ and (Z)-N-benzylidene-1-phenylmethanamine oxide 66 was selected to study the effects of all organocatalysts and ionic liquids, comparing the results with those obtained in classical conditions $\left(\mathrm{CH}_{2} \mathrm{Cl}_{2} ; 5^{\circ} \mathrm{C} ; 4 \mathrm{die}\right)$. In particular, any results were obtained when the authors used a combination of Cat-IV HCl and IL-VI. The combination of MacMillan-type imidazolidinone catalysts with $\mathrm{Cl}^{-}$or $\mathrm{TfO}^{-}$as anion (Cat-IV.HCl and Cat-IV.HOTf, respectively), [bmim] $\mathrm{BF}_{4}$ as solvent. and $5{ }^{\circ} \mathrm{C}$ as reaction temperature reduced the reaction time in three studies, considerably increasing the diastereo- and enantiomeric ratio up to 92:8 and 91:9, respectively, for endo/exo ratio and ee of endo-isomer.

Unfortunately, in many cases, the yield was lower (17\%-51\%) than that obtained in classical conditions (45\%). The combination with other non-standard reaction conditions highly used in organic chemistry, such as the microwave or ultrasound irradiation [46-48], reduced the reaction time up to hours, however retaining similar stereoselectivity results.

\section{1,3-DC in Deep Eutectic Solvents}

\subsection{Deep Eutectic Solvents (DES)}

Deep eutectic solvents (DESs) are a new class of non-conventional solvents like ionic liquids. They are a eutectic mixture composed of Lewis or Brönsted acid (hydrogen bond donor commonly defined as HBDs) and bases in the form of salts (hydrogen bond acceptors commonly defined as HBAs), that can contain different types of anions and cations. In Figure 4, the most common hydrogen bond donors and hydrogen bonds acceptors are reported [49,50]. 


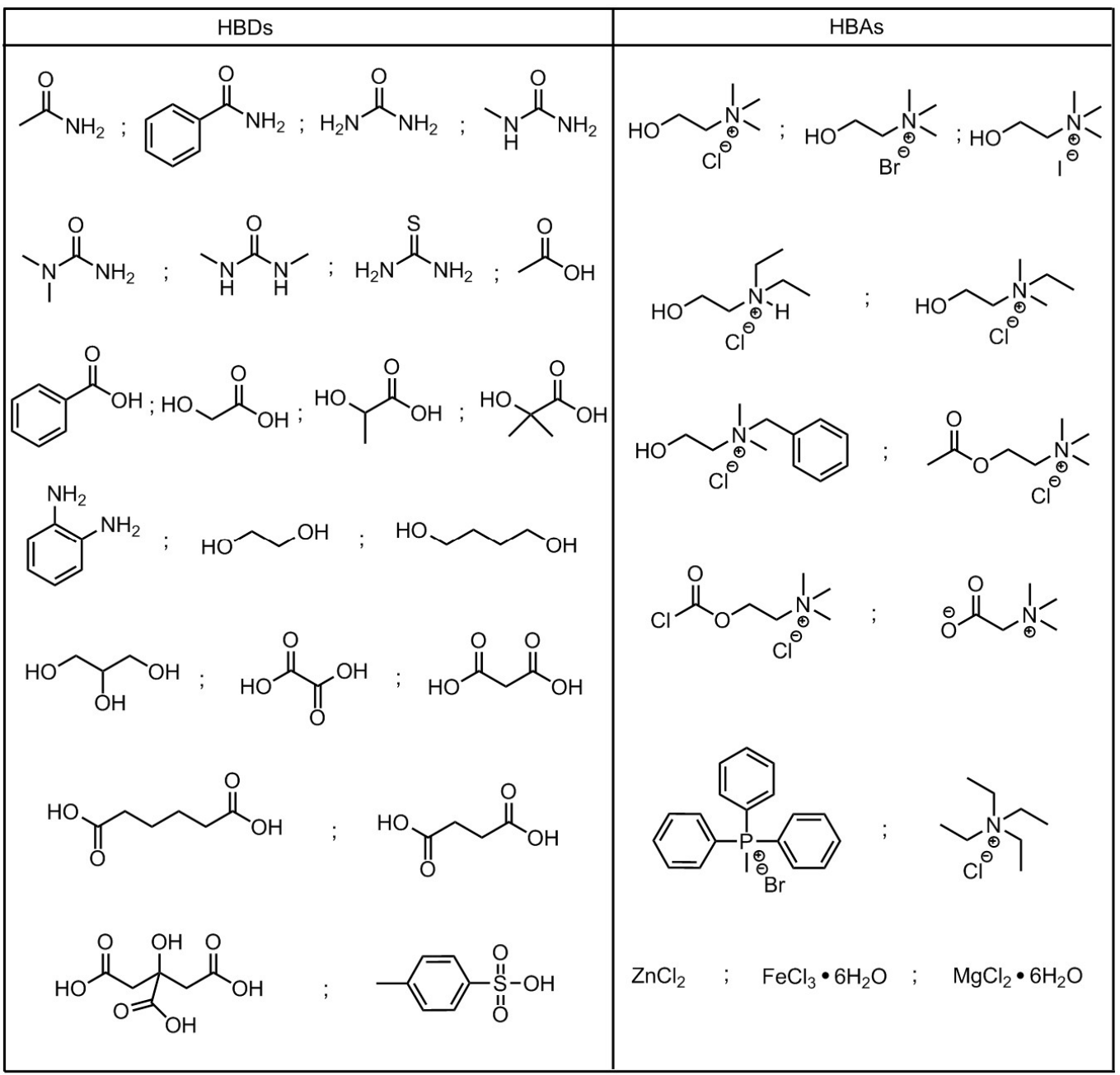

Figure 4. The most common hydrogen bond donors (HBDs) and hydrogen bond acceptors (HBAs) of deep eutectic solvent (DES) $[49,50]$.

This phase, composed of two or more components, generally does not form new chemical compounds through covalent bonds, but the main bonding interactions of non-covalent nature are: Hydrogen interactions, $\alpha$-hole interactions, $\pi$-hole interactions, and other two recently discovered as $\mathrm{k}$-hole and $\mu$-hole interactions [51]. The most relevant feature is the lower melting point compared with that of the single species and this new formed mixture is called eutectic [52]. Deep eutectic mixtures are commonly synthesized by different methods. The first is the most commonly used and consists in mixing the components under heating $\left(60-100{ }^{\circ} \mathrm{C}\right)$, until the mixture became a colorless liquid. The second makes use of a mortar to grind the components at room temperature until a liquid is formed. The third method employs water to dissolve the components and then this solution is freeze-dried to form a clear liquid; if necessary, the water may be removed under high vacuum evaporation.

Thanks to many chemical-physical properties like high viscosity and density, conductivity, surface tension, high boiling points, eco-friendly character, low toxicity, and recyclability, the field of application of these materials is wide and includes biocatalysis, organocatalysis, separation processes like $\mathrm{CO}_{2}$ capture, biomass processing, metal processing, azeotrope breaking, organometallics, and synthesis [53]. DESs are employed as reaction medium for many green and eco-sustainable organic synthetic procedures [54]. For example, Punzi et al. recently described a Pd-catalyzed procedure for the thiophene-aryl coupled in deep eutectic solvent composed of choline chloride and urea (1:2), using non-anhydrous conditions, in an open-air system [55]. In other recent works, 1,2- or 2-substituted benzimidazoles were synthesized in a reactive DESs composed of $o$-phenylenediamine and choline 
chloride [56], while bio-renewable DESs were efficient for furfural transformation into cyclopentenone derivatives [57].

\subsubsection{Synthesis of Triazoles and Triazolines}

In 2016, Martins and co-workers developed a synthetic strategy to produce 1,4-disubtituted-1,2,3 triazoles 72 by 1,3-dipolar cycloaddition between azides 70 as 1,3-dipole and $\beta$-enaminones $\mathbf{7 1}$ as dipolarophile in a DES composed of choline chloride:ethylene glycol (1:2) (Scheme 13) [58].

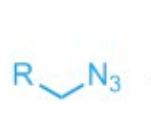

70<smiles>[R]C(=O)C=CN</smiles>

71

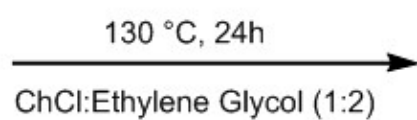

ChCl:Ethylene Glycol (1:2)<smiles>[R]C(=O)c1cn(CC)nn1</smiles>

72

\begin{tabular}{ccc}
\hline $\mathbf{R}$ & $\mathbf{R}^{\mathbf{1}}$ & Yield (\%) \\
\hline $\mathrm{Ph}$ & $\mathrm{Ph}$ & 81 \\
$\mathrm{Heptyl}$ & $\mathrm{Ph}$ & 70 \\
$4-\mathrm{OMeC}_{6} \mathrm{H}_{4}$ & $\mathrm{Ph}$ & 83 \\
$4-\mathrm{ClC}_{6} \mathrm{H}_{4}$ & $\mathrm{Ph}$ & 77 \\
$\mathrm{Ph}$ & $4-\mathrm{MeC}_{6} \mathrm{H}_{4}$ & 84 \\
$\mathrm{Ph}$ & $4-\mathrm{OMeC}_{6} \mathrm{H}_{4}$ & 83 \\
$\mathrm{Ph}$ & $4-\mathrm{BrC}_{6} \mathrm{H}_{4}$ & 82 \\
$\mathrm{Ph}$ & $4-\mathrm{IC}_{6} \mathrm{H}_{4}$ & 83 \\
$\mathrm{Ph}$ & $4-\mathrm{NO}_{2} \mathrm{C}_{6} \mathrm{H}_{4}$ & 77 \\
$\mathrm{Ph}$ & $\mathrm{Napht}^{2}-\mathrm{yl}$ & 83 \\
$\mathrm{Ph}$ & $4,4^{\prime}$-biphenyl & 84 \\
\hline
\end{tabular}

Scheme 13. Synthesis of 1,4-disubtituted-1,2,3 triazoles 72 in DES [58].

Initially, they optimized the reaction conditions changing some parameters such as DES type, temperature, and reaction time, observing that in choline chloride:ethylene glycol (1:2) at $130{ }^{\circ} \mathrm{C}$ after $24 \mathrm{~h}$, the final product was recovered in complete conversion and high yield. In actuality, the best performance was carried out using choline chloride and urea in ratio 1:2, but these reaction conditions were not employed on other substrates because DES decomposition related to ammonia production was observed. Then, several azides and enaminones were used isolating 4-acyl-1-subtituted-1,2,3triazoles in good reaction yields $(70 \%-84 \%)$. The authors also hypothesized a plausible reaction mechanism involving a series of interactions between DES and the reagents as reported in Figure 5.

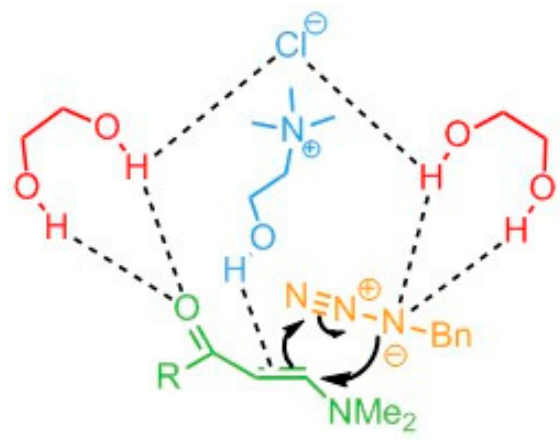

73

Figure 5. Proposed interactions between reagents and DES [58].

More specifically, one molecule of ethylene glycol interacts with the carbonyl group of the enaminone by hydrogen bond, while the second forms a hydrogen bond with azide. Choline chloride 
interacts through hydroxyl groups with the double bond of the enaminone to push up the reaction towards the product formation. Finally, the authors investigated the reusability of the DES by multiple recovery and after four cycles, DES composed of choline chloride and ethylene glycol was proved to maintain the same efficiency in terms of yield and conversion.

In 2018, Sebest and co-workers developed a synthetic procedure to form 1,2,3-triazolines 76 by direct 1,3-dipolar azide-alkene cycloaddition reaction in a series of DESs (Scheme 14) [59].
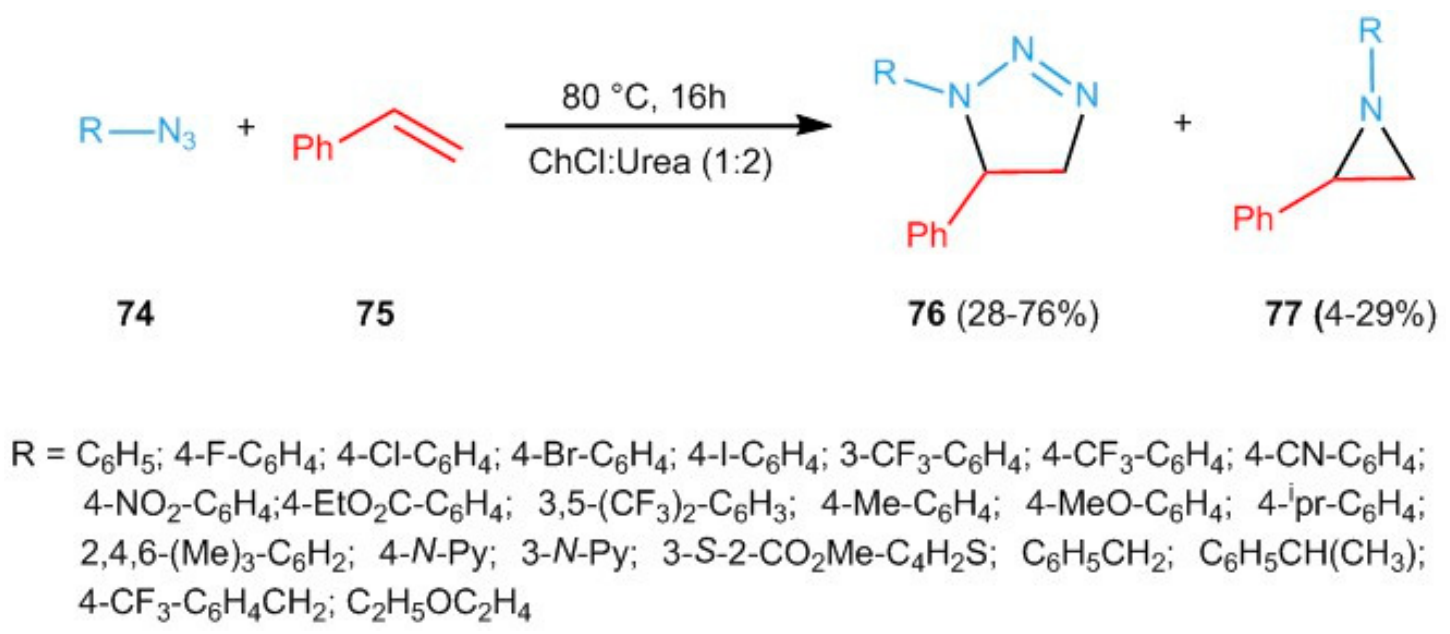

Scheme 14. Synthesis of 1,2,3-triazolines 76 by 1,3-dipolar azide-alkene cycloaddition reaction in DES [59].

The initial investigation on a model reaction highlighted, firstly, the formation of a second product of reaction of aziridine nature 77, deriving by triazoline decomposition, and that the use of different DESs had a prevalent effect on its yield. The best performance was achieved by choline chloride/urea $1: 2$, obtaining triazoline derivative in $67 \%$ yield and aziridine substrate in $22 \%$ yield.

The results were compared to those obtained by classical organic solvents, isolating the products in poor yields due to a decomposition of triazoline, prevented by DES use. Then, once the best reaction conditions were found, the authors made a screening using the same alkene (styrene) with several aromatic or aliphatic azides to study the effect of the substituents on the outcome of the reaction. In particular, they noticed that a trifluoromethane group in meta position of phenyl substituent of azide gave the corresponding triazoline surprisingly with an increase of the yield up to $76 \%$, while electron-donating substituents slightly increased the yield in aziridines (27\%-28\%) with a decrease of the triazoline yield (46\%-51\%). In analogous manner, mono- and disubstituted alkenes were also investigated, observing elevated yield of triazoline due to the steric hindrance of the dipholarophile (i.e., norbornene). Finally, DFT studies confirmed the formation of triazoline by 1,3dipolar cycloaddition, while aziridine formation was related to triazoline decomposition.

\subsubsection{Synthesis of Isoxazoles and Isoxazolines}

In 2015, Pérez and Ramón developed a synthetic method to access several 3,5-disubstituted isoxazoles and isoxazolines in a specific DES composed of choline chloride and urea as reaction medium by regioselective three-step 1,3-DC reaction (Scheme 15) [60].

The reaction started from different aldehydes 78 that were converted in the respective hydroxyminoyl chlorides $\mathbf{8 0}$. Then, these last substrates were employed as 1,3-dipoles in the subsequent cycloaddition reaction with reagents possessing triple bonds $\mathbf{8 1}$ to obtain 3,5-disubstituted isoxazoles $\mathbf{8 2}$.

The optimization of the process was conducted prevalently varying the DES, electing the mixture choline chloride/urea 1:2 as the system with the best performance. After the optimization of the reaction conditions, a series of isoxazoles $\mathbf{8 2}$ were synthesized in $63 \%-96 \%$ yield. 


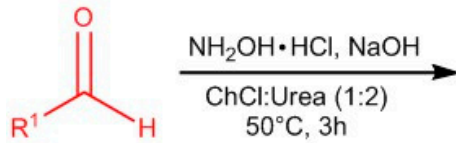

78<smiles>[R7]/C=N\O</smiles>

79

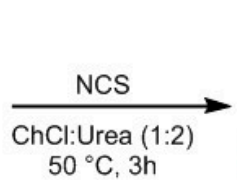

80<smiles>[R]C#CC</smiles>

81

$\mathrm{R}^{1}=\mathrm{Ph} ; 4-\mathrm{Cl}-\mathrm{Ph} ; 4-\mathrm{Me}-\mathrm{Ph} ; 2-\mathrm{Me}-\mathrm{Ph} ; \mathrm{C}_{6} \mathrm{H}_{11} ; 2$-quinolyl; 2-thienyl $\mathrm{R}^{2}=\mathrm{Ph} ; 3-\mathrm{Cl}-\mathrm{Ph} ; 4-\mathrm{MeO}-\mathrm{Ph} ; 2$-pyridyl; $\mathrm{C}_{6} \mathrm{H}_{11}$

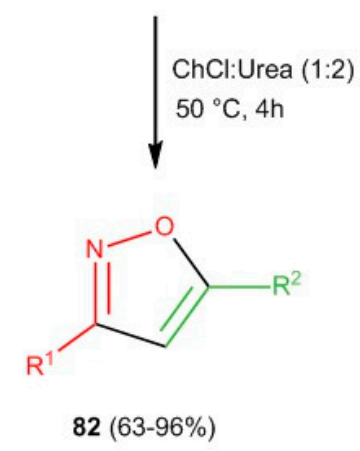

Scheme 15. Sinthesis of 3,5-disubstituted isoxazoles 82 in DES [60].

Moreover, the same authors investigated the cycloaddition reaction between the previous hydroxyminoyl chlorides $\mathbf{8 0}$ with substituted alkenes $\mathbf{8 3}$, obtaining 3,5-disubstituted isoxazolines $\mathbf{8 4}$, as reported in Scheme 16.

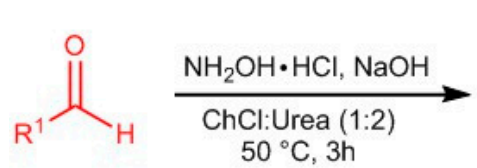

78<smiles>[R]/C=N\O</smiles>

79

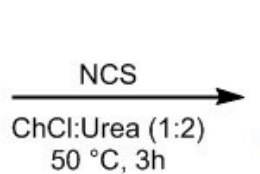

80<smiles>[R]C=CC</smiles>

83

$\mathrm{R}^{1}=\mathrm{Ph} ; 4-\mathrm{Cl}-\mathrm{Ph} ; 4-\mathrm{Me}-\mathrm{Ph} ; 2-\mathrm{Me}-\mathrm{Ph} ; 4-\mathrm{NO}_{2}-\mathrm{Ph}$; 2-thienyl $\mathrm{R}^{2}=\mathrm{Ph} ; 4-\mathrm{Cl}-\mathrm{Ph} ; 4-\mathrm{MeO}-\mathrm{Ph} ; 2$-pyridyl; $\mathrm{C}_{6} \mathrm{H}_{13} ; \mathrm{CH}_{2} \mathrm{Br}$

ChCl:Urea (1:2)

$50^{\circ} \mathrm{C}, 4 \mathrm{~h}$

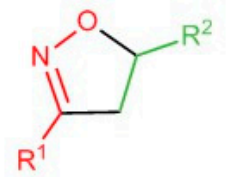

$84(42-91 \%)$

Scheme 16. Synthesis of 3,5-disubstituted isoxazolines 84 in DES [60].

In particular, they noticed that high yields were obtained in presence of heterocyclic rings on starting aldehydes or alkenes, while low yields resulted in aliphatic groups as substituents.

The developed procedure was also tested on the reaction between ethyl 2-nitroacetate 85 as 1,3-dipole and arylacetylenes $\mathbf{8 1}$ as dipholarophile in DES composed of acetyl choline chloride:urea (1:2), at $100{ }^{\circ} \mathrm{C}$ for $24 \mathrm{~h}$ to obtain ethyl 5-substituted isoxazoles-3-carboxylates 86 (Scheme 17).

As expected, aliphatic alkyne gave the lowest yield. The position of the substituents slightly influences the reaction yields with the best outcome in the case of aromatic rings substituted on the C-3 respect to that substituted on C-4. 


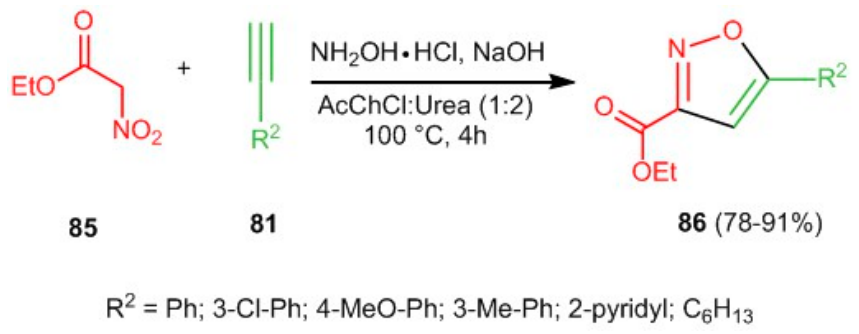

Scheme 17. Synthesis of ethyl 5-substituted isoxazole-3-carboxylates 86 in DES [60].

\subsubsection{Synthesis of Spiroheterocycles}

In 2019, Periyasami et al. synthesized dispiro-3-phenylpyrrolothiazoles 90 by 1,3-dipolar cycloaddition reaction in a deep eutectic solvent composed of acetyl choline iodide-ethylene glycol (ACI/EG) in good yield and short reaction times (Scheme 18) [61].

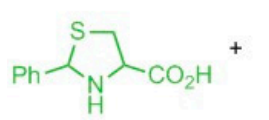

87

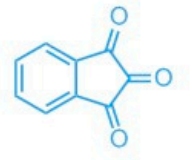

88

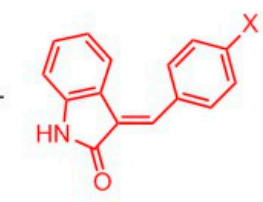

89

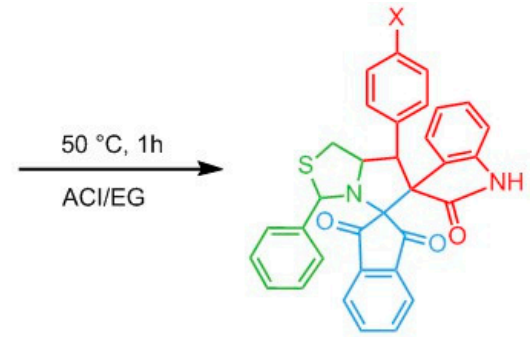

$90(85-92 \%)$

$\mathrm{X}=\mathrm{H}, \mathrm{OMe}, \mathrm{Me}, \mathrm{Cl}, \mathrm{Br}, \mathrm{NME}_{2}, \mathrm{CN}, \mathrm{NO}_{2}$

Scheme 18. Synthesis of dispiro-3-phenylpyrrolothiazoles 90 by 1,3-DC in DES [61].

In detail, the cyclic aminoacid 2-phenyl-1,3-thiazolidine-4-carboxylic acid 87 reacted with ninhydrin triketone 88 to generate in situ azomethyne ylide, through a mechanism of decarboxylative condensation. The formed ylide reacted with several 3-arylidene oxindoles 89 by one-pot 1,3-dipolar cycloaddition reaction to give the corresponding dispiro-heterocyclic compounds 90 in $85-92 \%$ yield.

The authors started the investigation with a screening of different non-conventional solvents as ionic liquid and DESs. When ionic liquids were used, mediocre reaction yields were obtained except when the reactions were carried out in DESs composed of ACI/EG in a ratio 1:9. Moreover, the dependence between temperature and reaction yield was visible, with higher yields at $50{ }^{\circ} \mathrm{C}$ than room temperature. The presence of a para-substituent on the aromatic ring of the dipolarophile did not affect the reaction yield, which was excellent both with electron-donating and electron-withdrawing groups. The reaction is regio- and diastereoselective toward one isomer due to the approach of the reagents shown in the transition state 91 in Figure 6.

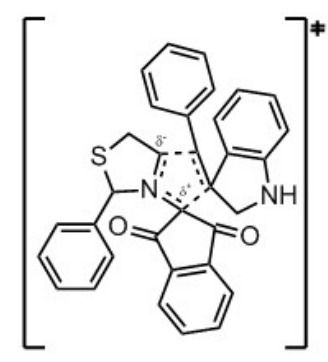

91

Figure 6. Transition state for the 1,3 dipolar cycloaddition reaction between an ylide produced in situ and the dipolarophile 89 [61]. 


\section{1,3-DC in Water}

The use of water as an eco-compatible solvent in organic chemistry reactions has always stimulated researchers to find several applications. Obviously, the low solubility of most organic compounds in this solvent is problematic to use it without the presence of an organic co-solvent.

Anyway, though this possible solution tends to diminish the great advantages due to the employment of water (low cost, nontoxicity, easy work-up, and product isolation in water), many syntheses have been performed recently in aqueous media with very good results [62-64].

Some studies of pericyclic cycloadditions showed great benefits when insoluble reagents were suspended in water, explicating this effect due to a reaction rate acceleration for the "on water" conditions [65]. In particular, comparative studies of 1,3-dipolar cycloadditions in organic solvents with water as a co-solvent or only in pure water showed a remarkable rate acceleration increase, probably due to hydrophobic effects with organic reagents, a lowering of activation energy by hydrogen bonds in the transition state, and an increased solvation stabilization [66].

\subsection{Synthesis of Spiroisoxazolidines}

In 2014, a three-component additive-assisted 1,3-dipolar cycloaddition between isatine derivatives 92, benzylamine 93, and substituted arylideneacetones $\mathbf{9 4}$ was proposed from Luo and collaborators to perform functionalized spirooxindoles $\mathbf{9 5}$ in good to excellent yields and good regioselectivity (Scheme 19) [67].

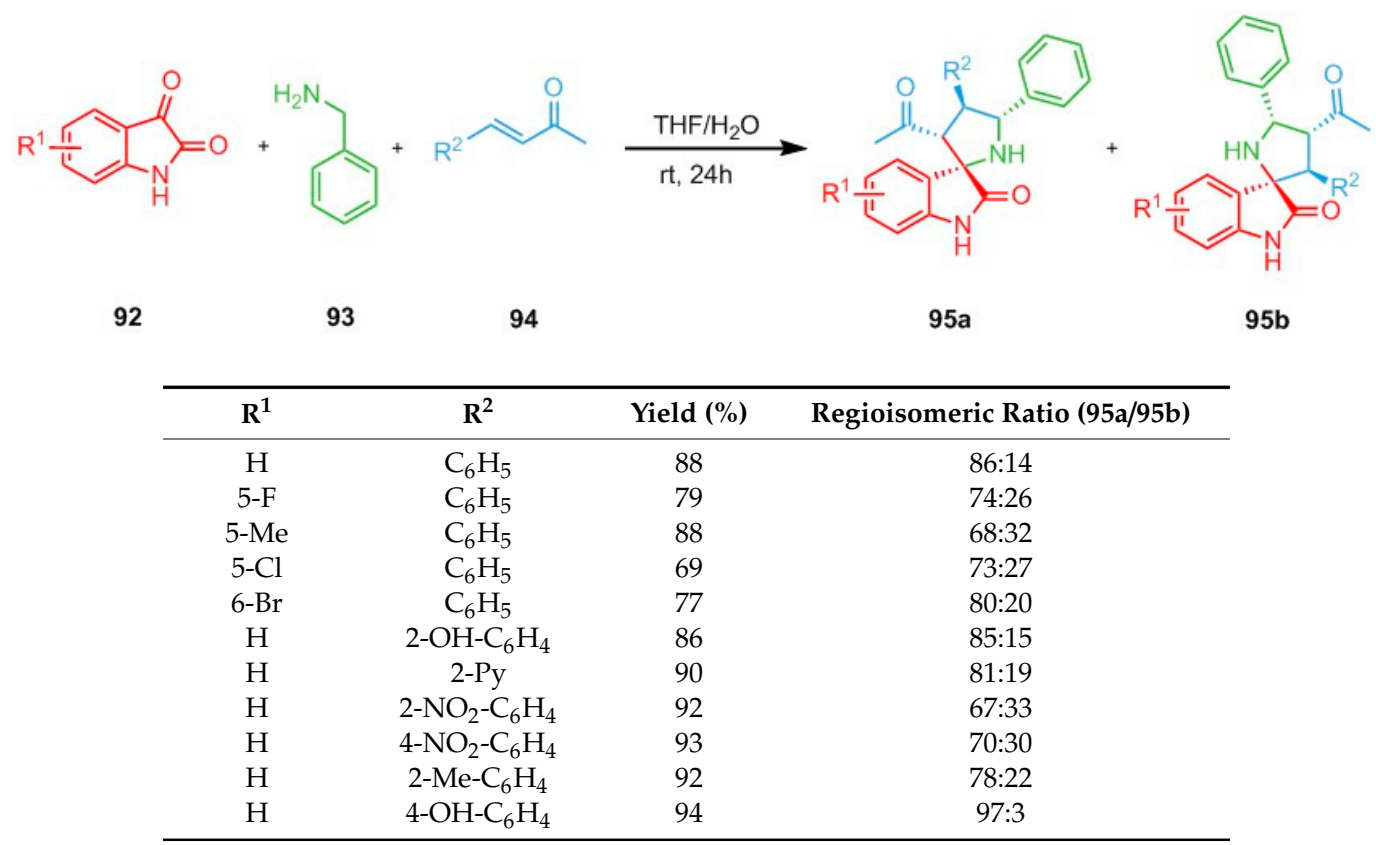

Scheme 19. Regioselective synthesis of spirooxindoles 95 by an additive-assisted 1,3-DC [67].

In particular, the additive presence of water (5 equiv) to tetrahydrofuran, solvent of reaction, led to non-only higher yields but also more elevated regioisomeric ratio than in absence of it. The authors explicated that the water plays an important action prevalently in one of the transition states in which it participates in an intermolecular hydrogen bond with two carbonyl groups of reagents (Figure 7). 


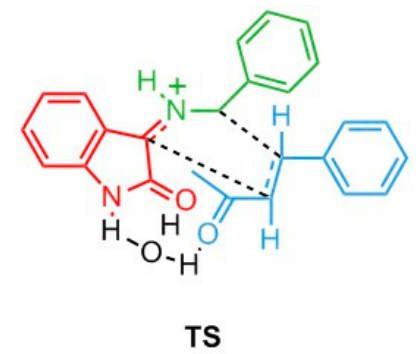

Figure 7. More favorite transition state with intermolecular interactions of water and reagents [67].

Moreover, they observed that the regioisomeric ratio underwent an increase when the phenyl rings of enones were substituted by electron-donating groups.

In 2015, Muthusamy et al. described an "on-water" generation of carbonyl ylide dipoles from diazoamides 96 to synthesize spiroindolo-oxiranes 98 and -dioxolanes 99 by a 1,3-dipolar cycloaddition reaction in water between the in-situ formed dipoles and aromatic aldehydes $\mathbf{9 7}$ having electron-donating/-withdrawing substituents (Scheme 20) [68].

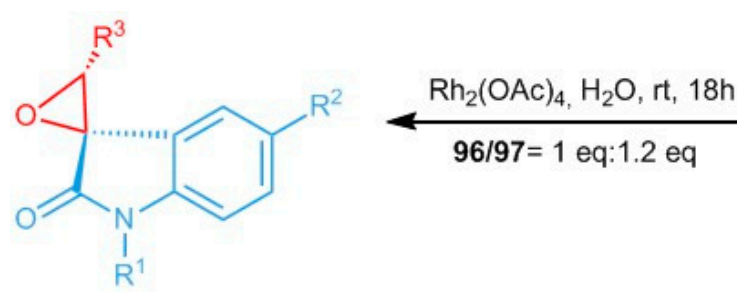

$98(0-67 \%)$<smiles>[R]c1ccc2c(c1)C(=N)C(=O)N2[R]</smiles>

96<smiles>[R]C=CCCC</smiles>

97

$\mathrm{R}^{1}=\mathrm{Me} ; \mathrm{Bn} ;$ Propargyl; Ts; Et

$\mathrm{R}^{2}=\mathrm{H} ; 5-\mathrm{Cl}$

$\mathrm{R}^{3}=4-\mathrm{MeO}-\mathrm{C}_{6} \mathrm{H}_{4} ; 3-\mathrm{MeO}-\mathrm{C}_{6} \mathrm{H}_{4} ; \mathrm{C}_{6} \mathrm{H}_{5} ; 2,3-(\mathrm{MeO})_{2}-\mathrm{C}_{6} \mathrm{H}_{3}$; 2,5-(MeO) $)_{2}-\mathrm{C}_{6} \mathrm{H}_{3} ; 4-\mathrm{NO}_{2} \mathrm{C}_{6} \mathrm{H}_{4} ; 1$-Naphtyl; 2-Naphtyl; $4-\mathrm{Cl}-\mathrm{C}_{6} \mathrm{H}_{4} ; 2-\mathrm{Br}_{-} \mathrm{C}_{6} \mathrm{H}_{4} ; 4-\mathrm{F}-\mathrm{C}_{6} \mathrm{H}_{4} ; 4-\mathrm{NMe}_{2}-\mathrm{C}_{6} \mathrm{H}_{4}$

$\mathrm{Rh}_{2}(\mathrm{OAc})_{4}, \mathrm{H}_{2} \mathrm{O}, \mathrm{rt}, 18 \mathrm{~h}$

$96 / 97=1$ eq: 4 eq<smiles>[R]c1ccc2c(c1)[C@]1(O[C@@H]([2H])O[C@@H]1[R])C(=O)N2[R]</smiles>

$99(0-78 \%)$

Scheme 20. Synthesis of spiroindolo-oxiranes 98 and -dioxolanes 99 by 1,3-DC in water [68].

It is noteworthy that the variability of obtaining the different spiro-products $\mathbf{9 8}$ and $\mathbf{9 9}$ was generated only by diverse amount of used aldehyde (1.2 eq for 96 or 4 eq for 97 ). The reactions were catalyzed by rhodium (II) acetate dimer that provided the final products in a highly diastereoselective manner and discrete yields. The authors noticed an important substituent effect on the reaction yield. In particular, it was observed that the presence of a nitro or a dimethylamino group on the aromatic ring of the aldehyde did not lead to the formation of any product. Other catalysts were tested in an initial model reaction between 3-diazooxindole and 4-methoxybenzaldehyde, but in all cases, no product formation was not observed. In this case, it is possible to invoke an "on-water" effect using a less water-soluble catalyst as $\mathrm{Rh}_{2}(\mathrm{OAc})_{4}$ to amplify the heterogeneous nature of the system. 
In 2016, functionalized bis-spirooxindoles 103 were synthesized from Trivedi and co-workers by diastereoselective 1,3-dipolar cycloadditon of substituted isatins 100, benzylamines 101, and enones 102 in water and ceric ammonium nitrate (CAN) as catalyst at $100{ }^{\circ} \mathrm{C}$ (Scheme 21) [69].<smiles>[R]c1ccc2c(c1)C(=O)C(=O)N2</smiles><smiles>[R]c1ccc(CN)cc1</smiles>

101<smiles>O=C1Nc2ccccc2/C1=C/C(=O)c1ccccc1</smiles>

102<smiles>[R]c1ccc([C@@H]2N[C@]3(C(=O)Nc4ccc([R])cc43)C3(C(=O)Nc4ccccc43)[C@H]2C)cc1</smiles>

$103(65-86 \%)$

$$
\begin{aligned}
& \mathrm{R}^{1}=\mathrm{H}, \mathrm{Cl}, \mathrm{Br}, \mathrm{I}, \mathrm{Me}, \mathrm{MeO}, \mathrm{NO}_{2} \\
& \mathrm{R}^{2}=\mathrm{H}, \mathrm{MeO}, \mathrm{F}
\end{aligned}
$$

Scheme 21. Synthesis of bis-spirooxindoles 103 in water and ceric ammonium nitrate as catalyst [69].

The effect of substituents on isatin substrates was evaluated observing that the halogen groups gave spirooxindoles in high yields, while a methoxy group on the benzylamine substrates produced the final products in low yield in contrast to fluoro-functionalized benzylamines. Moreover, a preliminary screening of different solvents such as methanol, ethanol, dichloromethane, tetrahydrofuran, toluene, and acetonitrile in the presence of CAN was performed by the authors, noting a reduction of yields and an increase of reaction time with respect to the cycloaddition conducted in water.

More recently, $\mathrm{TiO}_{2}$ nanoparticles $\left(\mathrm{TiO}_{2} \mathrm{NP}\right)$ in aqueous media was proposed as a reaction system to prepare spirooxindole-pyrrolidines 107 via 1,3-dipolar cycloaddition between substituted isatins 104, benzylamines 105, and pyridyl enones 106 with excellent regio- and diastereoselectivity, very good yields (80\%-94\%), and very short reaction time (Scheme 22) [70].

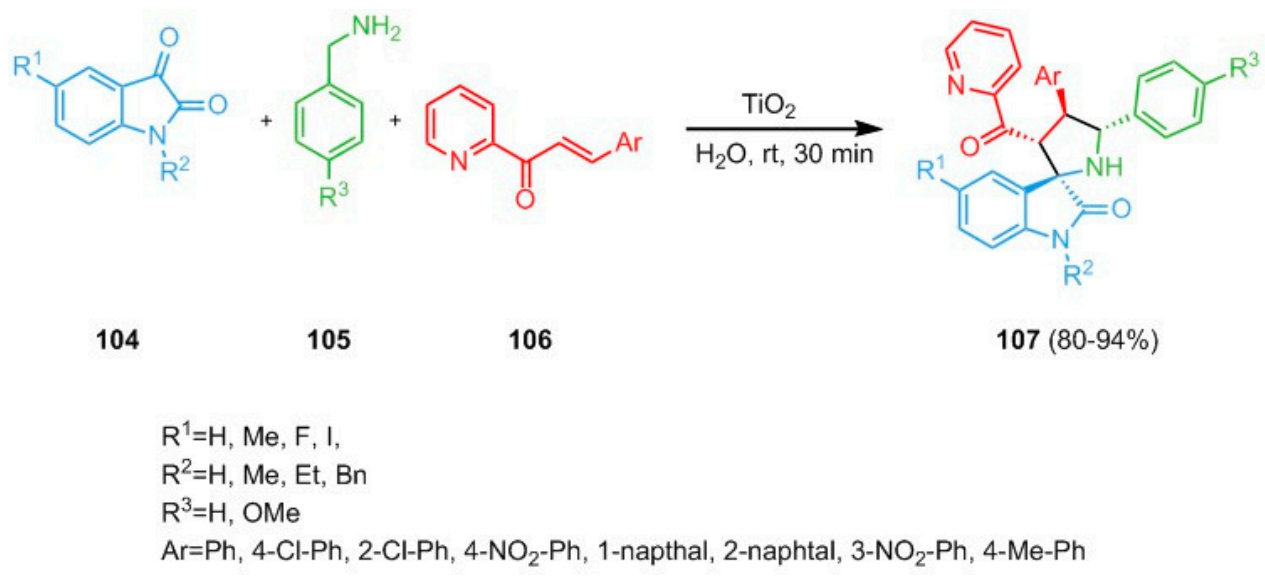

Scheme 22. Synthesis of spirooxindole-pyrrolidines 107 in aqueous media in presence of $\mathrm{TiO}_{2}$ nanoparticles [70].

A plausible mechanism of reaction was proposed that includes an initial immobilization of the reagents on the $\mathrm{TiO}_{2} \mathrm{NP}$ surface, facilitating the proximity of the substrate to react. Moreover, the authors proclaimed their protocol as rapid, green, column chromatography free, and with very good recyclability ( $90 \%$ after fourth run) of the heterogeneous catalyst. 


\subsection{Synthesis of Triazoles}

The copper-catalyzed azide-alkyne cycloaddition (CuAAC) is one of the most attractive reactions to produce 1,4-disubstituted 1,2,3-triazoles by 1,3-dipolar azide-alkyne cycloaddition [71,72].

However, metallic copper and copper salts are subject to redox processes, especially in aqueous media or in the presence of water as a co-solvent. For this reason, the recent efforts of scientists are directed towards the formation of protected and stabilized active copper catalysts.

Recently, polymer-stabilized $\mathrm{Cu}(\mathrm{I})$ catalyst and $\mathrm{Cu}(\mathrm{I})$-catalyzed azide-alkyne cycloaddition under eco-friendly reaction conditions were used to synthesize 1,4-disubstituted 1,2,3-triazoles 110 in a regioselective manner (Scheme 23) [73].

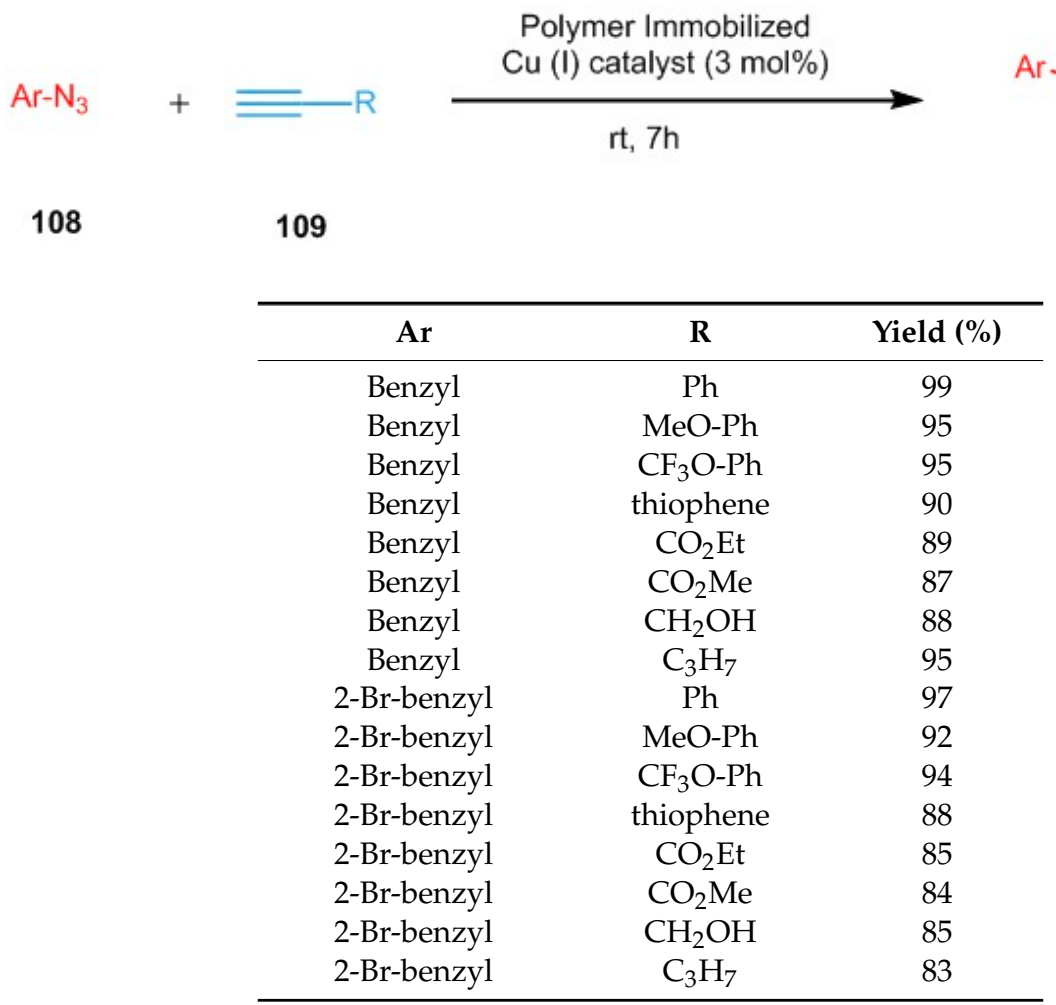

Scheme 23. Regioselective synthesis of 1,4-disubstituted 1,2,3-triazoles 110 by Cu-catalyzed 1,3-DC [73].

Initially, the polymer stabilized $\mathrm{Cu}(\mathrm{I})$ catalyst was prepared by aniline monomer diluted in methanol to which an aqueous solution of $\mathrm{CuSO}_{4} \cdot 5 \mathrm{H}_{2} \mathrm{O}$ was slowly added, isolating the polyaniline immobilized $\mathrm{Cu}(\mathrm{I})$ catalyst as a green solid.

Successively, this polymer was tested in 1,3-dipolar cycloadditions between benzylazide and phenyl acetylene in different solvent conditions including methanol or methanol-water (1:1), obtaining the final substituted triazole in high yield (99\%), elevated regioselectivity, and low reaction time. At the end, the heterogeneous catalyst was recovered by filtration to be reused for successive reactions without loss of activity. However, the authors preferred methanol as a solvent to perform the cycloaddition reactions on other substrates.

In 2017, Naeimi et al. realized copper/periodic mesoporous nanocomposites (Cu@PMO NCs), synthetized by the sol-gel method, to use in multicomponent 1,3-DC of organic halides 111, sodium azide 112, and alkynes 113 to prepare 1,4-disubstituted-1,2,3-triazoles 114 in water at $60^{\circ} \mathrm{C}$ (Scheme 24) [74]. 


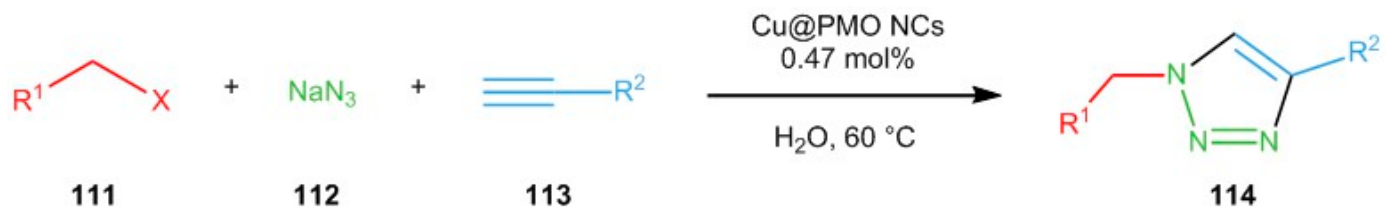

\begin{tabular}{ccc}
\hline $\mathbf{R}^{\mathbf{1}}$ & $\mathbf{R}^{\mathbf{2}}$ & Yield (\%) \\
\hline $\mathrm{C}_{6} \mathrm{H}_{5}$ & $\mathrm{Ph}$ & 94 \\
$4-\mathrm{Br}-\mathrm{C}_{6} \mathrm{H}_{4}$ & $\mathrm{Ph}$ & 92 \\
$4-\mathrm{NO}_{2}-\mathrm{C}_{6} \mathrm{H}_{4}$ & $\mathrm{Ph}$ & 96 \\
$3-\mathrm{NO}_{2}-\mathrm{C}_{6} \mathrm{H}_{4}$ & $\mathrm{Ph}$ & 87 \\
$2,4-\left(\mathrm{NO}_{2}\right)_{2}-\mathrm{C}_{6} \mathrm{H}_{3}$ & $\mathrm{Ph}$ & 85 \\
$2-\mathrm{Cl}_{2}-\mathrm{C}_{6} \mathrm{H}_{4}$ & $\mathrm{Ph}$ & 87 \\
$3-\mathrm{Cl}_{4}-\mathrm{C}_{6} \mathrm{H}_{4}$ & $\mathrm{Ph}$ & 84 \\
$2-\mathrm{Cl}-5-\mathrm{F}_{4} \mathrm{C}_{6} \mathrm{H}_{3}$ & $\mathrm{Ph}$ & 83 \\
$\mathrm{C}_{6} \mathrm{H}_{5}$ & $4-$ Tolyl & 93 \\
$4-\mathrm{Br}_{5}-\mathrm{C}_{6} \mathrm{H}_{4}$ & $4-$ Tolyl & 87 \\
$4-\mathrm{NO}_{2}-\mathrm{C}_{6} \mathrm{H}_{4}$ & $4-$ Tolyl & 95 \\
$\mathrm{C}_{6} \mathrm{H}_{5}$ & $\mathrm{C}_{3} \mathrm{H}_{7}$ & 82 \\
\hline
\end{tabular}

Scheme 24. Synthesis of 1,4-disubstituted-1,2,3-triazoles 114 in water by copper/periodic mesoporous nanocomposites [74].

A plausible mechanism of the action of $\mathrm{Cu} / \mathrm{PMO}$ nanocomposites on the alkyne-organoazide cycloaddition contemplates the formation of a copper $\pi$-complex $\mathbf{1 1 5}$ or a copper acetylide $\mathbf{1 1 6}$ as intermediate (Figure 8).

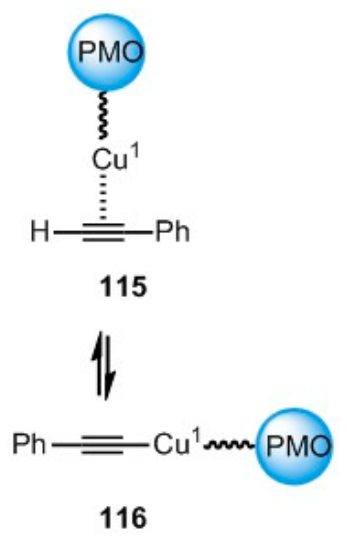

Figure 8. Copper $\pi$-complex $\mathbf{1 1 5}$ or copper acetylide $\mathbf{1 1 6}$ as the real intermediate in the alkyne-organoazide cycloaddition catalyzed by $\mathrm{Cu} / \mathrm{PMO}$ nanocomposite [74].

Finally, the $\mathrm{Cu} @ \mathrm{PMO}$ NCs catalyst was recovered by filtration and reused under similar conditions for six cycles without loss of catalytic activity.

More recently, mesoporous SBA-15, a versatile mesoporous silica material, was functionalized with copper (II) acetate to afford a novel $\mathrm{Cu}^{\mathrm{II}}$-Schiff base/SBA-15 catalyst 119. It was employed in three-component CuAAC reactions to obtain 1,4-disubstituted-1,2,3-triazoles 120 from organic halides 117, sodium azide 112, and alkynes 118 in water in good to excellent yield (51\%-97\%) and good regioselectivity (Scheme 25) [75]. 

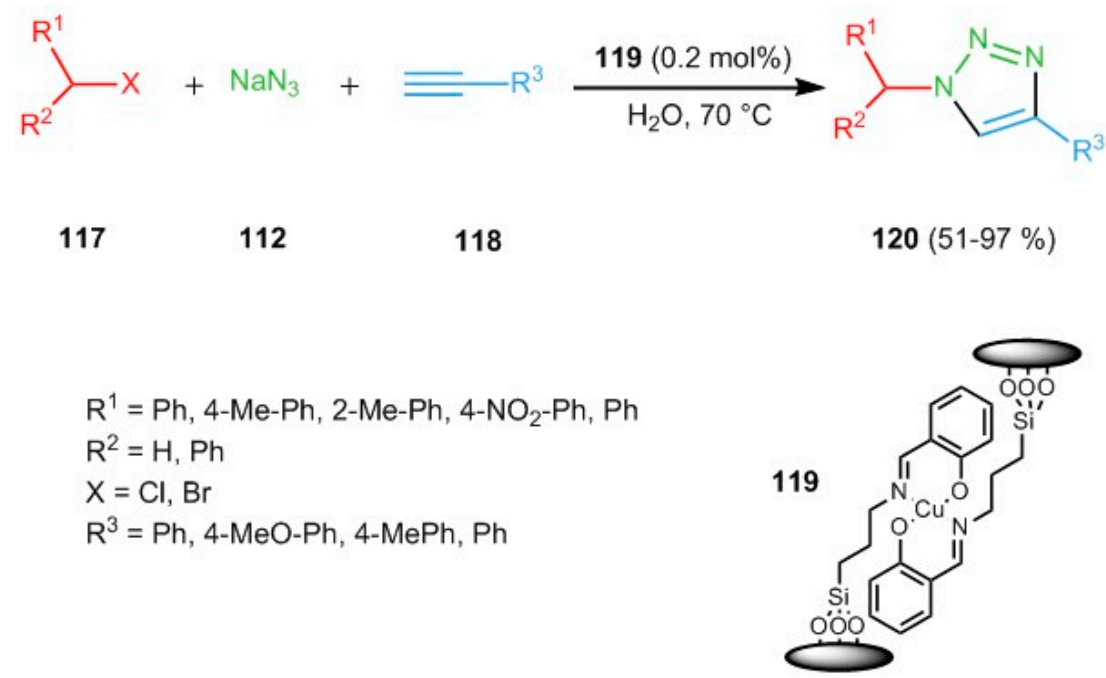

Scheme 25. Regioselective synthesis of 1,4-disubstituted-1,2,3-triazoles 120 in water by Cu-catalyst [75].

Finally, the catalyst was recycled for up to five consecutive cycles without any significant loss of efficiency.

\section{Conclusions}

The review is focused on the importance and applications of the most important green solvents such as ionic liquids (ILs), deep eutectic solvents (DES), and water in synthesis of heterocycles by catalyzed 1,3-dipolar cycloaddition reactions. In particular, in ionic liquids (ILs) several examples of regioselective synthesis of various heterocycle classes such as spirocycles, triazoles, isoxazolidines, and isoxazolines are described, with special attention to some cases of enantioselective induction by chiral cation of employed ionic liquid. In deep eutectic solvents (DES), regioselective 1,3-dipolar cycloaddition reactions to produce triazole derivatives, spirocycles, and isoxazole compounds are reported, with mechanistic deepening about the role of DES. Some examples of 1,3-dipolar cycloadditions are also explained in water, in which the greater reactivity of starting materials is justified through a "on-water effect". Moreover, ILs, DES, and water may be not only used as non-conventional solvents, but also as catalysts and catalyst supports. Finally, the great benefits of green approach are demonstrated by synthetic applications presented herein, such as the increased product yields and reaction rates, the recycling of solvent, and less complex work-up procedures.

The substantial advances described in this review fill the lack of reports on the most recent years (2014-2019), in which the scientific community, with great interest, has turned its attention towards more efficient, cheap, and eco-compatible procedures of catalyzed 1,3-dipolar cycloaddition reactions.

Funding: This research received no external funding.

Acknowledgments: We thank the University of Calabria for financial support.

Conflicts of Interest: The authors declare no conflict of interest.

\section{References}

1. Kobayashi, S.; Jorgensen, A.K. Cycloaddition Reactions in Organic Synthesis; Wiley: Weinheim, Germany, 2002.

2. Maiuolo, L.; De Nino, A.; Algieri, V.; Nardi, M. Microwave-Assisted 1,3-Dipolar Cycloaddition: Recent Advances In Synthesis of Isoxazolidines. Mini-Rev. Org. Chem. 2017, 14, 136-142. [CrossRef]

3. Woodward, R.B.; Hoffmann, R. The Conservation of Orbital Symmetry; Verlag Chemie: Weinheim, Germany, 1970.

4. Ratti, R. Ionic Liquids: Synthesis and Applications in Catalysis. Adv. Chem. 2014, 2014, 729842. [CrossRef] 
5. Pollet, P.; Davey, E.A.; Ureña-Benavides, E.E.; Eckert, C.A.; Liotta, C.L. Solvents for sustainable chemical processes. Green Chem. 2014, 16, 1034-1055. [CrossRef]

6. Lautens, M.; Klute, W.; Tam, W. Transition metal-mediated cycloaddition reactions. Chem. Rev. 1996, 96, 49-92. [CrossRef] [PubMed]

7. Pellissier, H. Asymmetric organocatalytic cycloadditions. Methods Org. Synth. 2012, 68, 2197-2232. [CrossRef]

8. Welton, T. Ionic liquids in catalysis. Coordin. Chem. Rev. 2004, 248, 2459-2477. [CrossRef]

9. Pârvulescu, V.I.; Hardacre, C. Catalysis in ionic liquids. Chem. Rev. 2007, 107, 2615-2665. [CrossRef]

10. Kaur, G.; Sharma, A.; Banerjee, B. [Bmim] PF6: An efficient tool for the synthesis of diverse bioactive heterocycles. J. Serb. Chem. Soc. 2018, 83, 1071-1097. [CrossRef]

11. Kaur, N. Perspectives of ionic liquids applications for the synthesis of five- and six-membered O,N-heterocycles. Synth. Commun. 2018, 48, 473-495. [CrossRef]

12. Welton, T. Room-temperature ionic liquids: Solvents for synthesis and catalysis. Chem. Rev. 1999, 99, 2071-2083. [CrossRef]

13. Welton, T. Ionic liquids: A brief hystory. Biophys. Rev. 2018, 10, 691-706. [CrossRef] [PubMed]

14. Goossens, K.; Lava, K.; Bielawski, C.W.; Binnemans, K. Ionic Liquid Crystals: Versatile Materials. Chem. Rev. 2016, 116, 4643-4807. [CrossRef] [PubMed]

15. Bini, R.; Chiappe, C.; Mestre, V.L.; Pomelli, C.S.; Welton, T. A theoretical study of the solvent effect on Diels-Alder reaction in room temperature ionic liquids using a supermolecular approach. Theor. Chem. Acc. 2009, 123, 347-352. [CrossRef]

16. Di Gioia, M.L.; Costanzo, P.; De Nino, A.; Maiuolo, L.; Nardi, M.; Olivito, F.; Procopio, A. Simple and efficient Fmoc removal in ionic liquid. RSC Adv. 2017, 7, 36482-36491. [CrossRef]

17. De Nino, A.; Maiuolo, L.; Merino, P.; Nardi, M.; Procopio, A.; Roca-López, D.; Russo, B.; Algieri, V. Efficient Organocatalyst Supported on a Simple Ionic Liquid as a Recoverable System for the Asymmetric Diels-Alder Reaction in the Presence of Water. ChemCatChem 2015, 7, 830-835. [CrossRef]

18. Turco Liveri, V.; Lombardo, D.; Pochylski, M.; Calandra, P. Molecular association of small amphiphiles: Origin of ionic liquid properties in dibutyl phosphate/propylamine binary mixtures. J. Mol. Liq. 2018, 263, 274-281. [CrossRef]

19. Calandra, P.; Mandanici, A.; Turco Liveri, V. Self-assembly in surfactant-based mixtures driven by acid-base reactions: Bis(2-ethylhexyl) phosphoric acid-n-octylamine systems. RSC Adv. 2013, 3, 5148-5155. [CrossRef]

20. Calandra, P.; Nicotera, I.; Rossi, O.C.; Liveri, T.V. Dynamical properties of self-assembled surfactant-based mixtures: Triggering of 1D anomalous diffusion in bis(2-ethylhexyl) phosphoric acid/n-octylamine systems. Langmuir 2013, 29, 14848-14854. [CrossRef]

21. Pochylski, M.; Rossi, O.C.; Nicotera, I.; Liveri, T.V.; Calandra, P. Nano-demixing as a novel strategy for magnetic field responsive systems: The case of Dibutyl phosphate/ Bis(2-Etylhexyl)amine systems. RSC Adv. 2016, 16, 26696-26708. [CrossRef]

22. Calandra, P.; Liveri, T.V.; Riello, P.; Freris, I.; Mandanici, A. Self-assembly in surfactant-based liquid mixtures: Octanoic acid/Bis(2-ethylhexyl)amine systems. J. Colloid Interface Sci. 2012, 367, 280-285. [CrossRef]

23. Nicotera, I.; Rossi, O.C.; Liveri, T.V.; Calandra, P. Decoupling of dynamic processes in surfactant-based liquid mixtures: The case of lithium-containing bis(2-ethylhexyl)phosphoric acid/bis(2-ethylhexyl)amine systems. Langmuir 2014, 30, 8336-8341. [CrossRef] [PubMed]

24. Arun, Y.; Bhaskar, G.; Balachandran, C.; Ignachimuthu, S.; Perumal, P.T. Facile one-pot synthesis of novel dispirooxindole-pyrrolidine derivatives and their antimicrobial and anticancer activity against A549 human lung adenocarcinoma cancer cell line. Bioorg. Med. Chem. Lett. 2013, 23, 1839-1845. [CrossRef] [PubMed]

25. Maiuolo, L.; Feriotto, G.; Algieri, V.; Monica, N.; Russo, B.; Di Gioia, M.L.; Furia, E.; Tallarida, M.A.; Mischiati, C.; De Nino, A. Antiproliferative activity of novel isatinyl/indanyl nitrones (INs) as potential spin trapping agents of free radical intermediates. MedChemComm 2018, 9, 299-304. [CrossRef] [PubMed]

26. Maiuolo, L.; Vincenzo, A.; Russo, B.; Tallarida, M.A.; Nardi, M.; Di Gioia, M.L.; Merchant, Z.; Merino, P.; Delso, I.; De Nino, A. Synthesis, Biological and In Silico Evaluation of Pure Nucleobase-Containing Spiro (Indane-Isoxazolidine) Derivatives as Potential Inhibitors of MDM2-p53 Interaction. Molecules 2019, 24, 2909. [CrossRef]

27. Almansour, A.I.; Arumugam, N.; Kumar, R.S.; Periyasami, G.; Ghabbour, H.A.; Fun, H.-K. A Novel One-Pot Green Synthesis of Dispirooxindolo-pyrrolidines via 1,3-Dipolar Cycloaddition Reactions of Azomethine Ylides. Molecules 2015, 20, 780-791. [CrossRef] 
28. Kumar, R.S.; Almansour, A.I.; Arumugam, N.; Basiri, A.; Kia, Y.; Kumar, R.R. Ionic liquid-promoted synthesis and cholinesterase inhibitory activity of highly functionalized spiropyrrolidines. Aust. J. Chem. 2015, 68, 863-871. [CrossRef]

29. Gothelf, K.V.; Jørgensen, K.A. Asymmetric 1,3-Dipolar Cycloaddition Reactions. Chem. Rev. 1998, 98, 863-909. [CrossRef]

30. Maiuolo, L.; Merino, P.; Algieri, V.; Nardi, M.; Di Gioia, M.L.; Russo, B.; Delso, I.; Tallarida, M.A.; De Nino, A. Nitrones and nucleobase-containing spiroisoxazolidines derived from isatin and indanone: Solvent-free microwave-assisted stereoselective synthesis and theoretical calculations. RSC Adv. 2017, 7, 48980-48988. [CrossRef]

31. Siriram, D.; Bal, T.R.; Yogeeswari, P. Aminopyrimidinimino isatin analogues: Design of novel non- nucleoside HIV-1 reverse transcriptase inhibitors with broad-spectrum chemotherapeutic properties. J. Pharm. Sci. 2005, 8, 565-577.

32. Wang, S.; Zhao, Y.; Bernard, D.; Aguilar, A.; Kumar, S. Targeting the MDM2-p53 Protein-Protein Interaction for New Cancer Therapeutics. Cold Spring Harb. Perspect. Med. 2017, 7, a026245. [CrossRef]

33. Bach, D. Organic Synthesis-Where now? Angew. Chem. Int. Ed. 1990, 29, 1320-1367. [CrossRef]

34. Chakraborty, B.; Chettri, E. Synthesis of Some Novel Class of Regioselective Spiro Isoxazolidine Derivatives via 1,3-Dipolar Cycloaddition Reaction of N-Benzyl-C- fluorosubstituted Phenyl Nitrones in Ionic Liquid. J. Heterocycl. Chem. 2018, 55, 1157-1165. [CrossRef]

35. Thirumurugan, P.; Matosiuk, D.; Jozwiak, K. Click chemistry for drug development and diverse chemical-biology applications. Chem. Rev. 2013, 113, 4905-4979. [CrossRef] [PubMed]

36. Sadeghpour, H.; Khabnadideh, S.; Zomorodian, K.; Pakshir, K.; Hoseinpour, K.; Javid, N.; Faghih-Mirzaei, H.; Rezaei, Z. Design, Synthesis, and Biological Activity of New Triazole and Nitro-Triazole Derivatives as Antifungal Agents. Molecules 2017, 22, 1150. [CrossRef] [PubMed]

37. De Nino, A.; Merino, P.; Algieri, V.; Nardi, M.; Di Gioia, M.L.; Russo, B.; Tallarida, M.A.; Maiuolo, L. Synthesis of 1,5-Functionalized 1,2,3-Triazoles Using Ionic Liquid/Iron(III) Chloride as an Efficient and Reusable Homogeneous Catalyst. Catalysts 2018, 8, 364. [CrossRef]

38. Maiuolo, L.; Russo, B.; Algieri, V.; Nardi, M.; Di Gioia, M.L.; Tallarida, M.A.; De Nino, A. Regioselective synthesis of 1,5-disubstituted 1,2,3-triazoles by1,3-dipolar cycloaddition: Role of $\operatorname{Er}(\mathrm{OTf})_{3}$, ionic liquid and water. Tetrahedron Lett. 2019, 60, 672-674. [CrossRef]

39. De Nino, A.; Algieri, V.; Tallarida, M.A.; Costanzo, P.; Pedrón, M.; Tejero, T.; Merino, P.; Maiuolo, L. Regioselective Synthesis of 1,4,5-Trisubstituted-1,2,3-Triazoles from Aryl Azides and Enaminones. Eur. J. Org. Chem. 2019, 2019, 5725-5731. [CrossRef]

40. Kumar, R.S.; Almansoura, A.I.; Arumugama, N.; Menéndez, J.C.; Osmanc, H.; Kumard, R.R. Dipolar Cycloaddition-Based Multicomponent Reactions in Ionic Liquids: A Green, Fully Stereoselective Synthesis of Novel Polycyclic Cage Systems with the Generation of Two New Azaheterocyclic Rings. Synthesis 2015, 47, 2721-2730. [CrossRef]

41. Sutariya, T.R.; Labana, B.M.; Parmar, N.J.; Kant, R.; Gupta, V.K.; Plata, G.B.; Padrón, J.M. Efficient synthesis of some new antiproliferative $N$-fused indoles and isoquinolines via 1,3-dipolar cycloaddition reaction in an ionic liquid. New J. Chem. 2015, 39, 2657-2668. [CrossRef]

42. Chakraborty, B.; Amalesh, S.; Sharma, C.D.; Khatun, N. Synthesis of some novel class of isoxazoline and isoxazolidine derivatives in ionic liquid via 1,3-dipolar cycloaddition reaction of dihydropyran derived nitrones and their antimicrobial activities. Indian J. Chem. 2014, 53B, 218-226. [CrossRef]

43. Nie, X.; Lu, C.; Chen, Z.; Yang, G.; Nie, J. Enantioselective 1,3-dipolar cycloadditions of nitrones with unsaturated aldehydes promoted by a recyclable tetraarylphosphonium supported imidazolidinone catalyst. J. Mol. Catal. A Chem. 2014, 393, 171-174. [CrossRef]

44. Shen, Z.L.; Gheong, H.L.; Lai, Y.C.; Loo, W.Y.; Loh, T.P. Application of recyclable ionic liquid-supported imidazolidinonecatalyst in enantioselective Diels-Alder reactions. Green Chem. 2012, 14, 2626-2630. [CrossRef]

45. Mojzesová, M.; Mečiarová, M.; Almássy, A.; Marti, R.; Šebesta, R. Assessment of non-standard reaction conditions for asymmetric 1,3-dipolar organocatalytic cycloaddition of nitrone with $\alpha, \beta$-unsaturated aldehydes. Chem. Pap. 2015, 69, 737-746. [CrossRef] 
46. Paonessa, R.; Nardi, M.; Di Gioia, M.L.; Olivito, F.; Oliverio, M.; Procopio, A. Eco-Friendly Synthesis of Lipophilic EGCG Derivatives and Antitumor and Antioxidant Evaluation. Nat. Prod. Commun. 2018, 13, 1117-1122. [CrossRef]

47. Nardi, M.; Di Gioia, M.L.; Costanzo, P.; De Nino, A.; Maiuolo, L.; Oliverio, M.; Olivito, F.; Procopio, A. Selective Acetylation of Small Biomolecules and their Derivatives Catalyzed by Er(OTf $)_{3}$. Catalysts 2017, 7, 269. [CrossRef]

48. Bortolini, O.; Fantin, G.; Fogagnolo, M.; Rossetti, S.; Maiuolo, L.; Di Pompo, G.; Avnet, S.; Granchi, D. Synthesis, characterization and biological activity of hydroxyl-bisphosphonic analogs of bile acids. Eur. J. Med. Chem. 2012, 52, 221-229. [CrossRef]

49. Smith, E.L.; Abbott, A.P.; Ryder, K.S. Deep eutectic solvents (DESs) and their applications. Chem. Rev. 2014, 114, 11060-11082. [CrossRef]

50. Chen, Y.; Yu, D.; Lu, Y.; Li, G.; Fu, L.; Mu, T. Volatility of Deep Eutectic Solvent Choline Chloride:N-Methylacetamide at Ambient Temperature and Pressure. Ind. Eng. Chem. 2019, 58, 7308-7317. [CrossRef]

51. Yu, D.; Mu, T. Strategy to Form Eutectic Molecular Liquids Based on Noncovalent Interactions. J. Phys. Chem. B 2019, 123, 4958-4966. [CrossRef]

52. Migliorati, V.; Sessa, F.; D'Angelo, P. Deep eutectic solvents: A structural point of view on the role of the cation. Chem. Phys. Lett. 2019, 2, 100001-100006. [CrossRef]

53. Rodriguez, N.R.; Van Den Bruin Horst, A.; Kollau, L.J.B.M.; Kroon, M.C.; Binnemans, K. Degradation of Deep-Eutectic Solvents Based on Choline Chloride and Carboxylic Acids. ACS Sustain. Chem. Eng. 2019, 7, 11521-11528. [CrossRef]

54. Clarke, C.J.; Tu, W.-C.; Levers, O.; Bröhl, A.; Hallett, J.P. Green and Sustainable Solvents in Chemical Processes. Chem. Rev. 2018, 118, 747-800. [CrossRef]

55. Punzi, A.; Coppi, D.I.; Matera, S.; Capozzi, M.A.M.; Operamolla, A.; Ragni, R.; Badubri, F.; Farinola, G.M. Pd-Catalyzed Thiophene-Aryl Coupling Reaction via C-H Bond Activation in Deep Eutectic Solvents. Org. Lett. 2019, 19, 4754-4757. [CrossRef]

56. Di Gioia, M.L.; Cassano, R.; Costanzo, P.; Herrera Cano, N.; Maiuolo, L.; Nardi, M.; Nicoletta, F.P.; Oliverio, M.; Procopio, A. Green Synthesis of Privileged Benzimidazole Scaffolds Using Active Deep Eutectic Solvent. Molecules 2019, 24, 2885. [CrossRef]

57. Di Gioia, M.L.; Nardi, M.; Costanzo, P.; De Nino, A.; Maiuolo, L.; Oliverio, M.; Procopio, A. Biorenewable Deep Eutectic Solvent for Selective and Scalable Conversion of Furfural into Cyclopentenone Derivatives. Molecules 2018, 23, 1891. [CrossRef] [PubMed]

58. Martins, M.A.P.; Paveglio, G.C.; Rodrigues, L.V.; Frizzo, C.P.; Zanatta, N.; Bonacorso, H.G. Promotion of 1,3-dipolar cicloaddition between azides and $\beta$-enaminones by deep eutectic solvents. New J. Chem. 2016, 40, 5989-5992. [CrossRef]

59. Sebest, F.; Casarrubios, L.; Rzepa, H.S.; White, A.J.P.; Diez-Gonzalez, S. Thermal azide alkene cycloaddition reactions: Straightforward multi-gram access to $\Delta 2-1,2,3$-triazolines in deep eutectic solvents. Green Chem. 2018, 20, 4023-4035. [CrossRef]

60. Peréz, J.M.; Ramón, D.J. Synthesis of 3,5-Disubstituted Isoxazoles and Isoxazolines in Deep Eutectic Solvents. ACS Sustain. Chem. Eng. 2015, 3, 2343-2349. [CrossRef]

61. Perihasami, J.; Ponmurugan, K.; Arumugam, N.; Sureshkumar, R.; Rahaman, M.; Periyan, D.; Al-Dhavi, N.A.; Alzakhy, S.; Aldalbahi, A. An expeditious and environmentally benign synthesis of dispiro-3-phenylpyrrolothiazoles in ACI/AG eutectic mixtures and its antioxidant and antimicrobial activities against urinary tract pathogens. BMC Chem. 2019, 13, 1-11. [CrossRef]

62. Nardi, M.; Costanzo, P.; De Nino, A.; Di Gioia, M.L.; Olivito, F.; Sindona, G.; Procopio, A. Water excellent solvent for the synthesis of bifunctionalized cyclopentenones from furfural. Green Chem. 2019, 19, 5403-5411. [CrossRef]

63. Olivito, F.; Costanzo, P.; Di Gioia, M.L.; Nardi, M.; Oliverio, M.; Procopio, A. Efficient synthesis of organic thioacetates in water. Org. Biomol. Chem. 2018, 16, 7753-7759. [CrossRef] [PubMed]

64. Olivito, F.; Amodio, N.; Di Gioia, M.L.; Nardi, M.; Oliverio, M.; Juli, G.; Tassone, P.; Procopio, A. Synthesis and preliminary evaluation of the anti-cancer activity on A549 lung cancer cells of a series of unsaturated disulfides. MedChemComm 2019, 10, 116-119. [CrossRef] [PubMed] 
65. Narayan, S.; Muldoon, J.; Finn, M.G.; Fokin, V.V.; Kolb, H.C.; Sharpless, K.B. “On Water”: Unique reactivity of organic compounds in aqueous suspension. Angew. Chem. Int. Ed. 2005, 44, 3275-3279. [CrossRef] [PubMed]

66. Martina, K.; Tagliapietra, S.; Veselov, V.V.; Cravotto, G. Green Protocols in Heterocycle Syntheses via 1,3-Dipolar Cycloadditions. Front. Chem. 2019, 7, 95. [CrossRef] [PubMed]

67. Peng, C.; Ren, J.; Xiao, J.-A.; Zhang, H.; Yang, H.; Luo, Y. Additive-assisted regioselective 1,3-dipolar cycloaddition of azomethine ylides with benzylideneacetone. Beilstein J. Org. Chem. 2014, 10, 352-360. [CrossRef] [PubMed]

68. Muthusamy, S.; Ramkumar, R. 'On-water' generation of carbonyl ylides from diazoamides: Rhodium(II) catalyzed synthesis of spiroindolo-oxiranes and -dioxolanes with an interesting diastereoselectivity. Tetrahedron 2015, 71, 6219-6226. [CrossRef]

69. Ramesh, P.; Rao, K.S.; Trivedi, R.; Kumar, B.S.; Prakasham, R.S.; Sridhar, B. Highly efficient regio and diastereoselective synthesis of functionalized bis-spirooxindoles and their antibacterial properties. RSC Adv. 2016, 6, 26546-26552. [CrossRef]

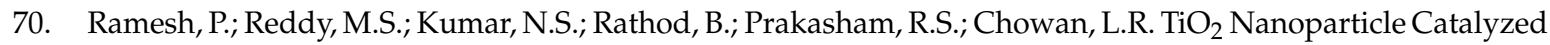
Rapid Synthesis of Spiroxindole-Pyrrolidine in Aqueous Medium and Evaluation of their Antimicrobial Properties. ChemistrySelect 2018, 3, 9096-9101. [CrossRef]

71. Tornøe, C.W.; Christensen, C.; Meldal, M. Peptidotriazoles on Solid Phase: [1,2,3]-Triazoles by Regiospecific Copper(I)-Catalyzed 1,3-Dipolar Cycloadditions of TerminalAlkynes toAzides. J. Org. Chem. 2002, 67, 3057-3064. [CrossRef]

72. Rostovtsev, V.V.; Green, L.G.; Fokin, V.V.; Sharpless, K.B. A Stepwise Huisgen. Cycloaddition Process: Copper(I)-Catalyzed Regioselective Ligation of Azides and Terminal Alkynes. Angew. Chem. Int. Ed. 2002, 41, 2596-2599. [CrossRef]

73. Islam, R.U.; Taher, A.; Choudhary, M.; Siwal, S.; Mallick, K. Polymer immobilized Cu(I) formation and azide-alkyne cycloaddition: A one pot reaction. Sci. Rep. 2015, 5, 9632-9639. [CrossRef] [PubMed]

74. Nejadshafiee, V.; Naeimi, H. Nanocomposite copper metal as an efficient heterogeneous catalyst in click synthesis of 1,2,3-triazoles in aqueous media. Turk. J. Chem. 2017, 41, 700-709. [CrossRef]

75. Bagherzadeha, M.; Mahmoudia, H.; Aminib, M.; Gautamc, S.; Chaed, K.H. SBA-15-supported copper (II) complex: An efficient heterogeneous catalyst for azide-alkyne cycloaddition in water. Sci. Iran. 2018, 25, 1335-1343. [CrossRef] 